University of the Pacific

Scholarly Commons

McGeorge School of Law Global Center for

Intercultural Legal Competence Workshop -

Business and Development Annual Symposium

August 2011

Aug 8th, 9:00 AM - 5:00 PM

\title{
Negotiating Globally: How to Negotiate Deals, Resolve Disputes, and Make Decisions Across Cultural Boundaries
}

Jeanne M. Brett

Follow this and additional works at: https://scholarlycommons.pacific.edu/global-center-symposium

Part of the Law Commons

Brett, Jeanne M., "Negotiating Globally: How to Negotiate Deals, Resolve Disputes, and Make Decisions Across Cultural Boundaries" (2011). McGeorge School of Law Global Center for Business and Development Annual Symposium. 1.

https://scholarlycommons.pacific.edu/global-center-symposium/august-2011/event/1

This Event is brought to you for free and open access by the McGeorge School of Law Symposia and Conferences at Scholarly Commons. It has been accepted for inclusion in McGeorge School of Law Global Center for Business and Development Annual Symposium by an authorized administrator of Scholarly Commons. For more information, please contact mgibney@pacific.edu. 


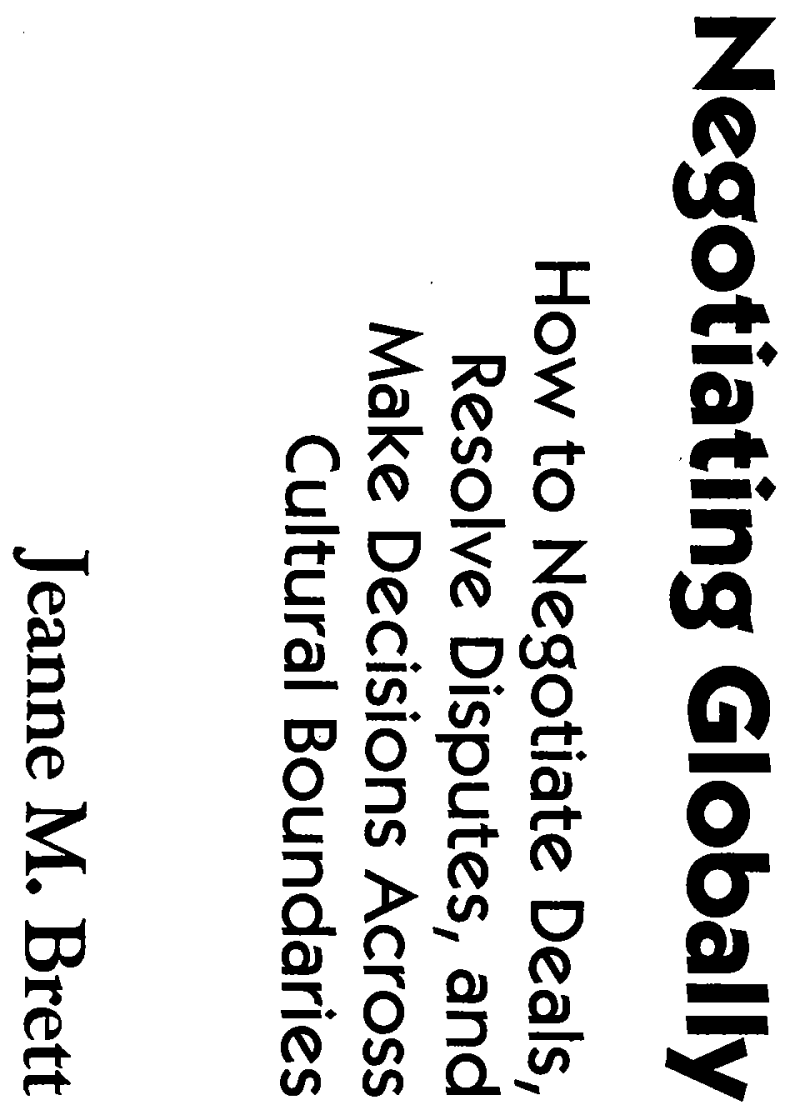



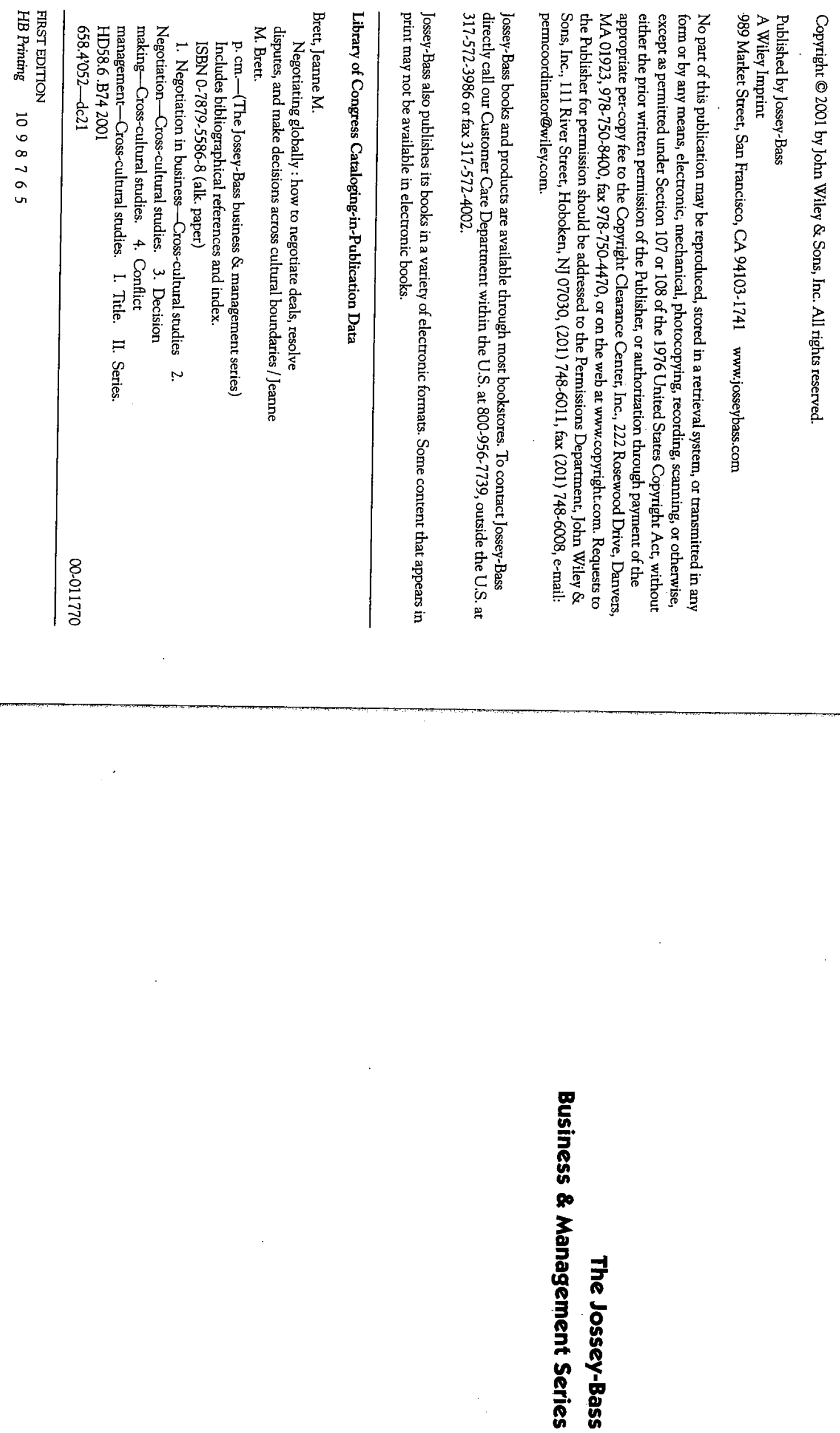


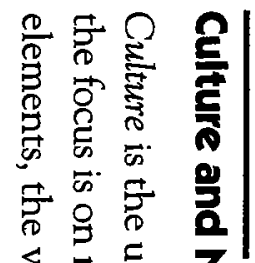

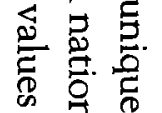

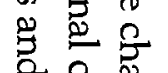

更

号宫

品

营

監

प्र

จㅇํㅇ

苛总

查 옹

吊票

祭官.

응

क्ष @

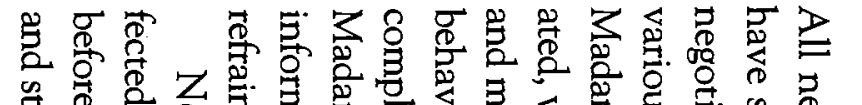

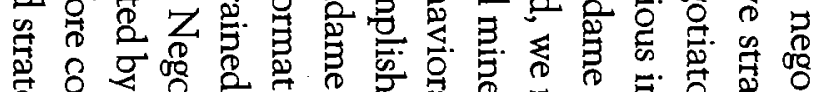

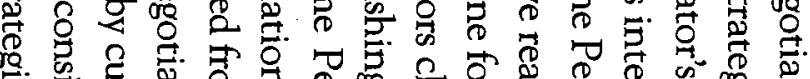

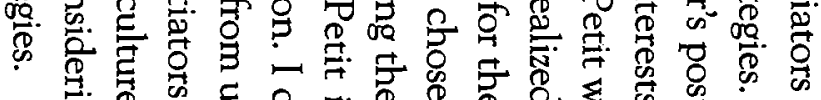

官

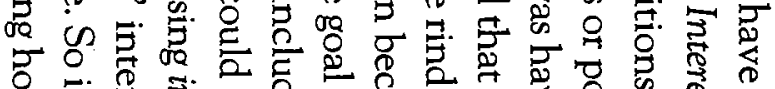

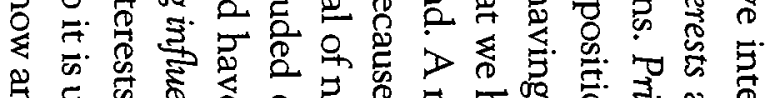

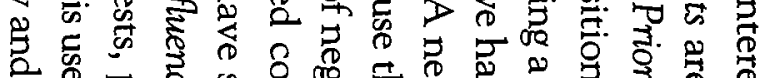

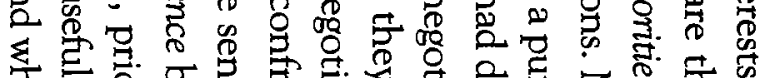

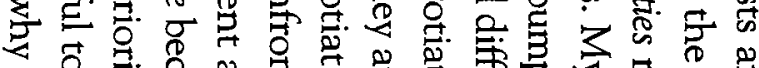

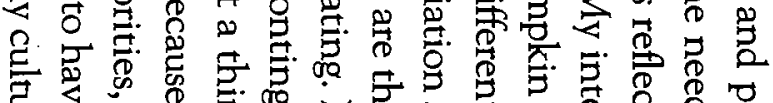

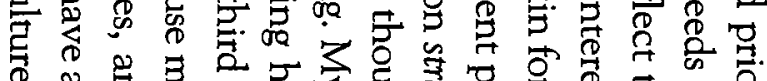

क

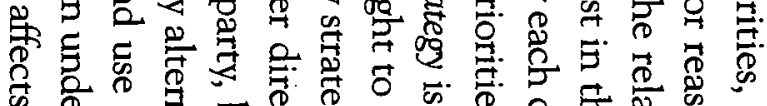

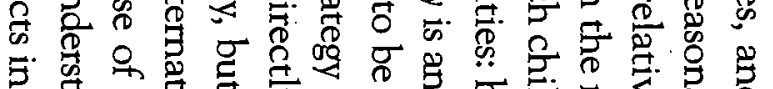

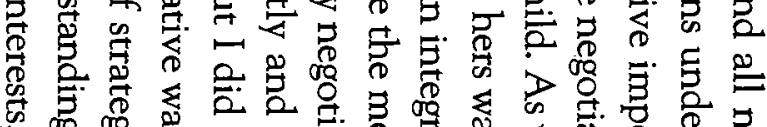

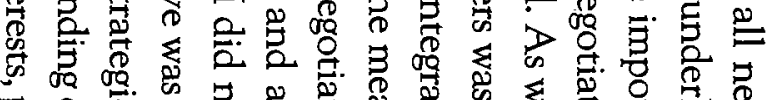

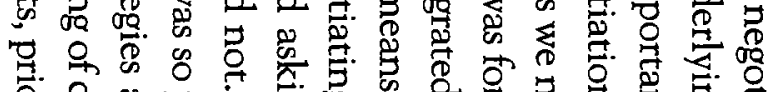

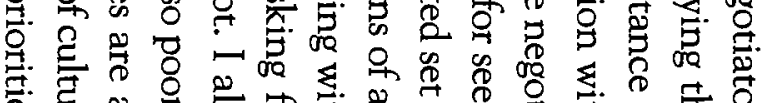

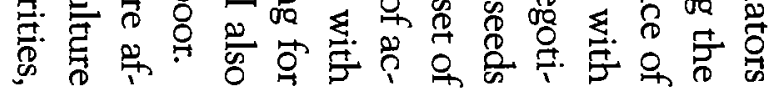

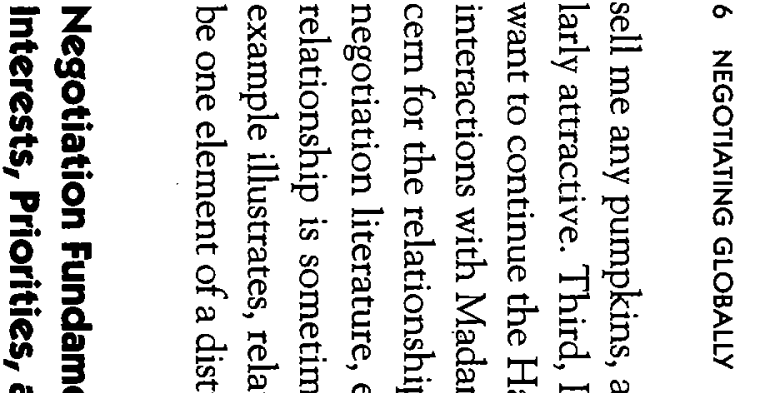

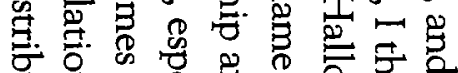

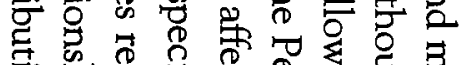

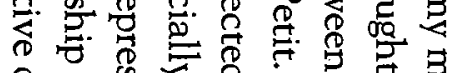

○ क

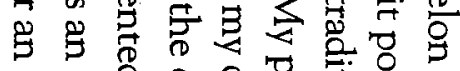

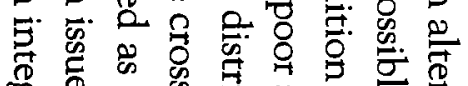

䚄

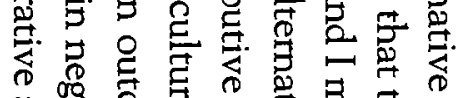

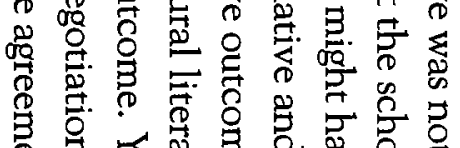

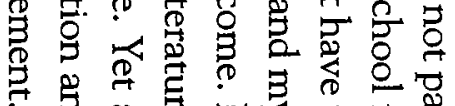

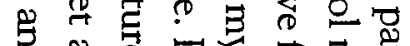

ठ

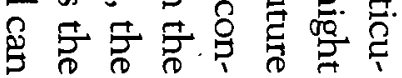

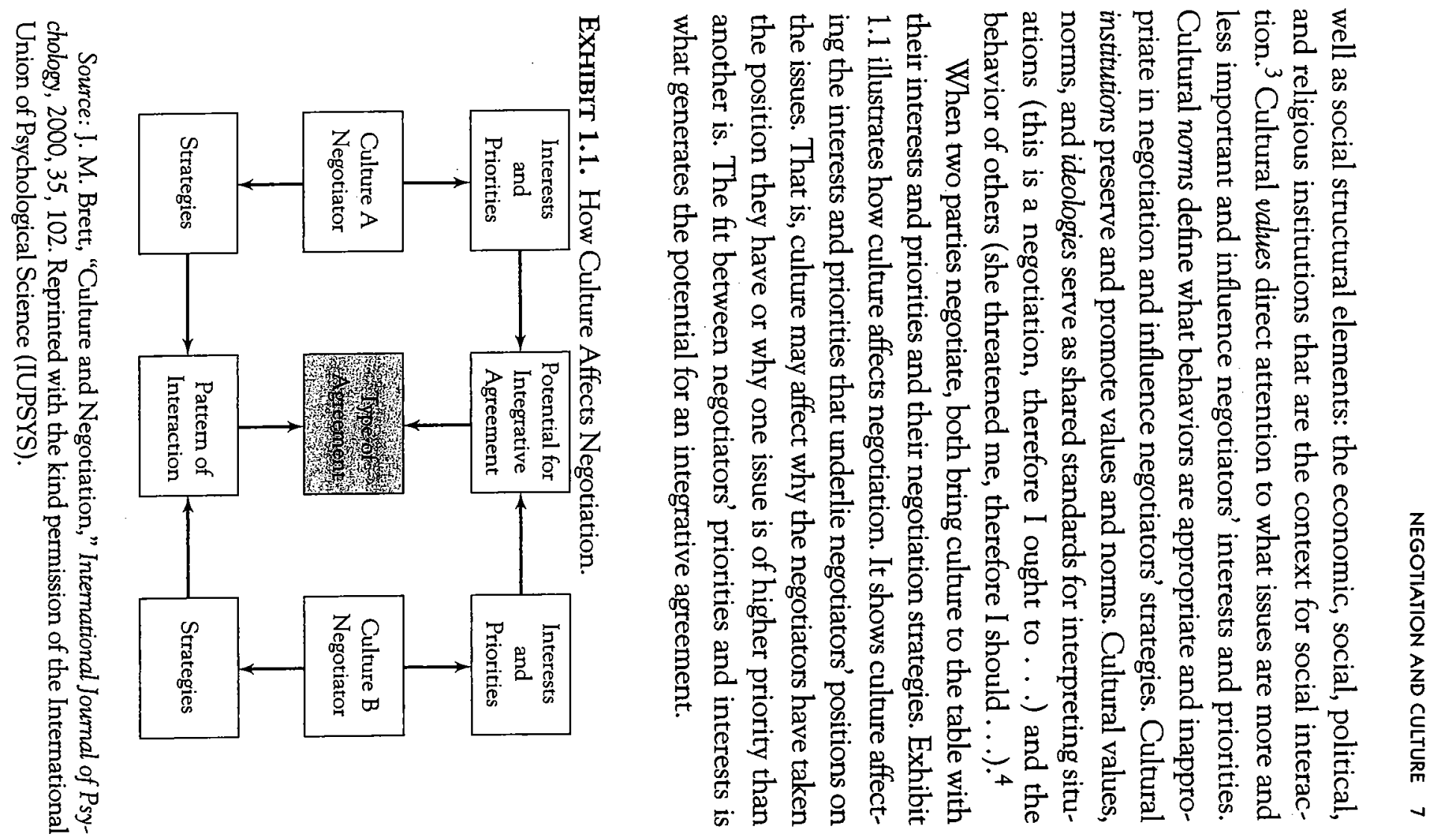




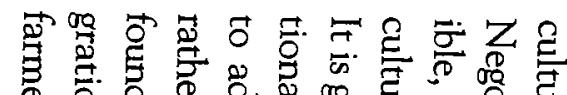

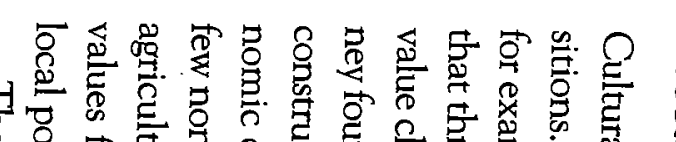

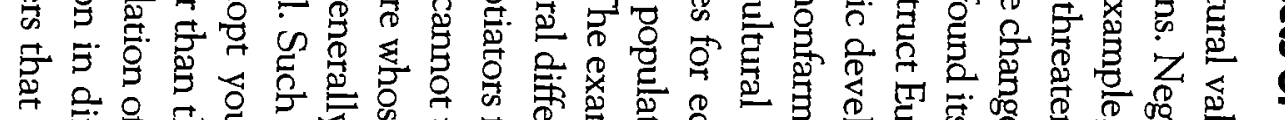

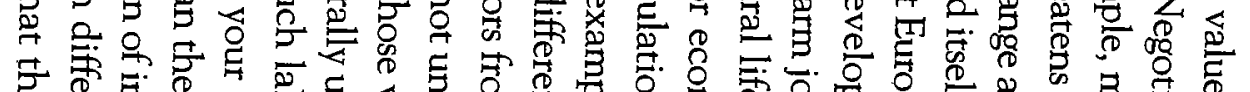

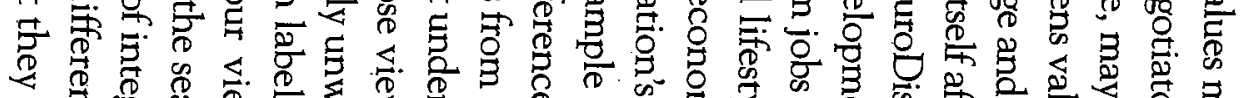

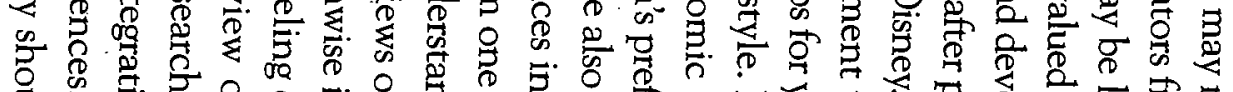

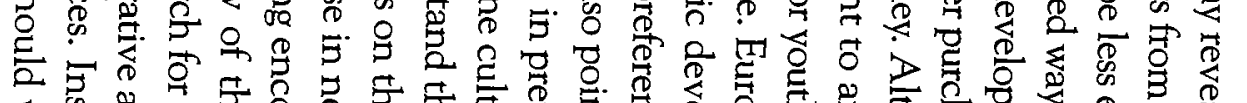

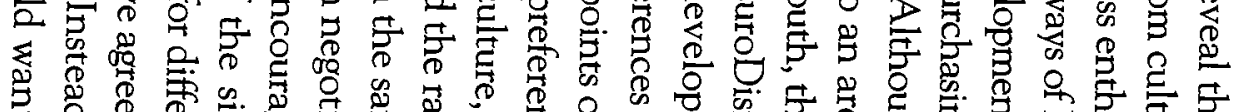

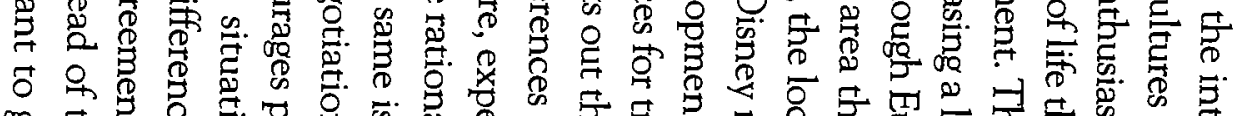

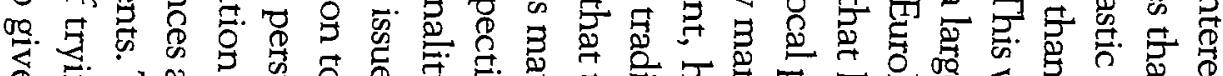

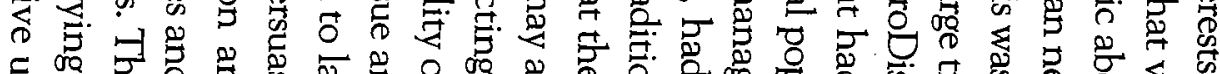

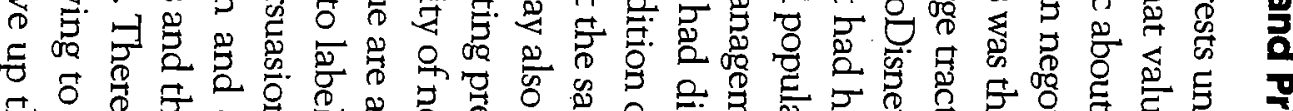

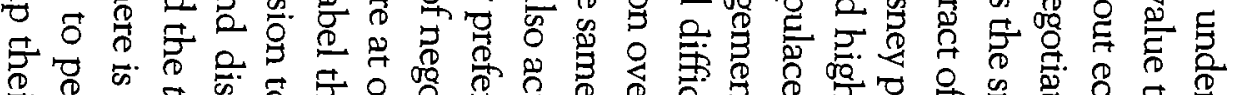

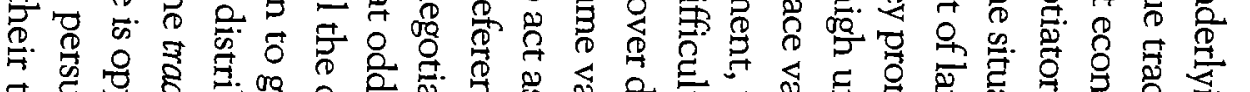

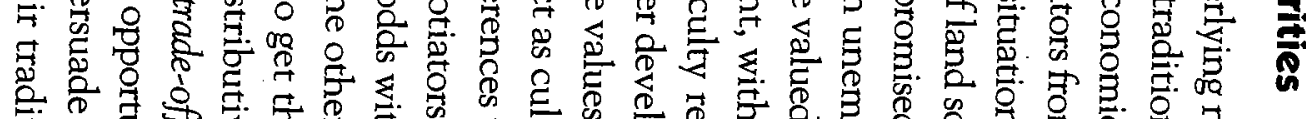

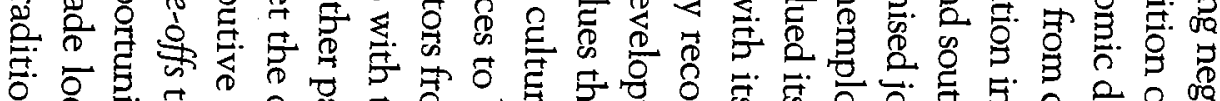

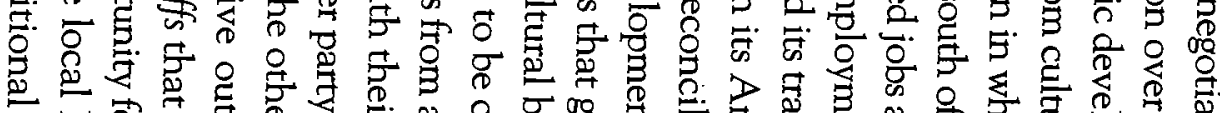

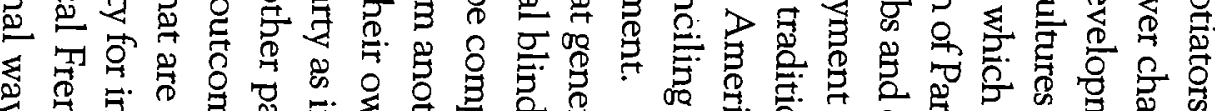

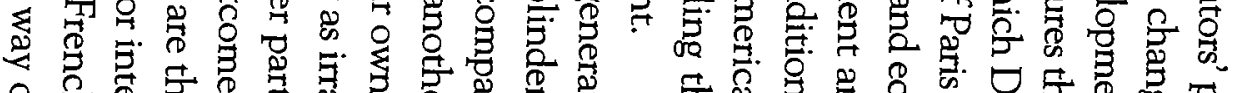

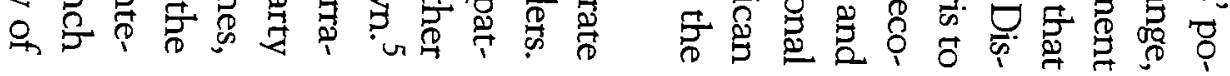

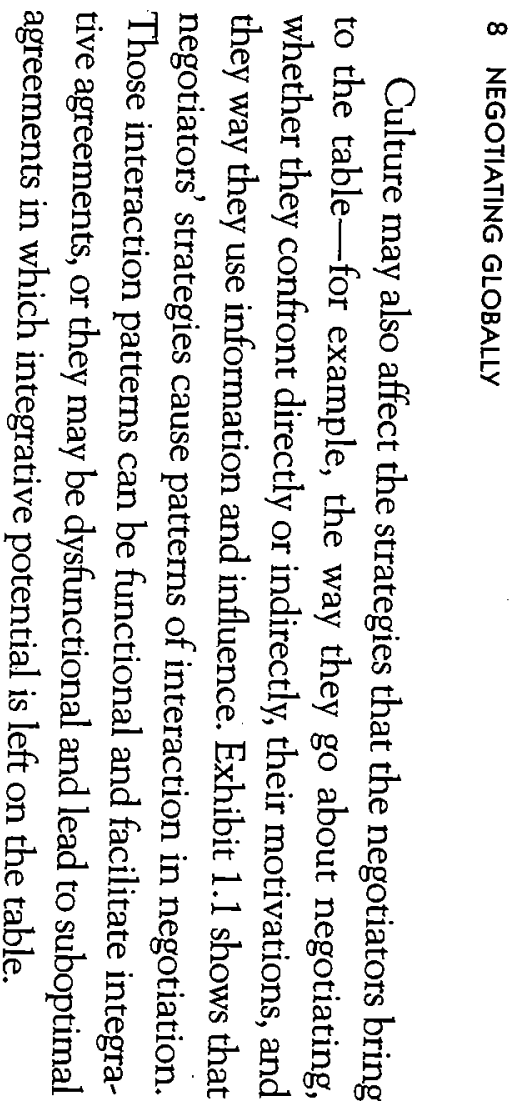

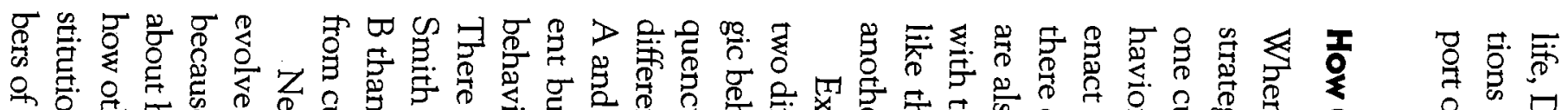

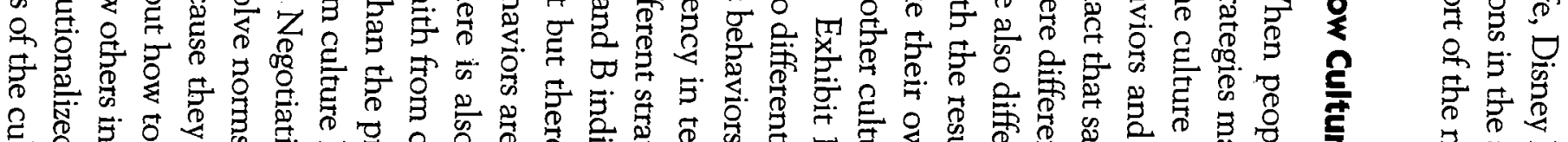

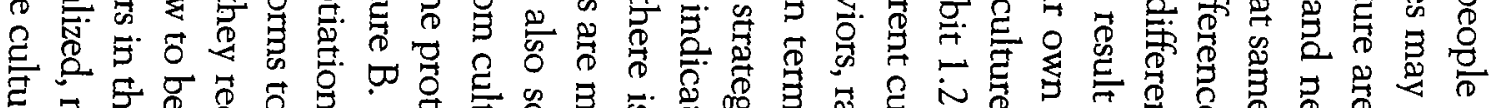

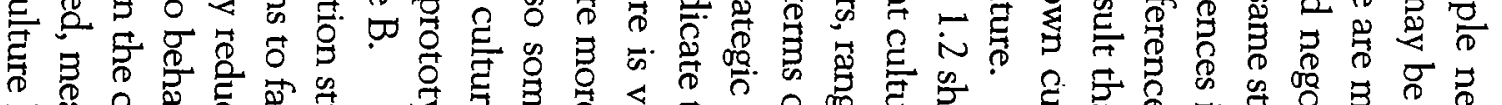

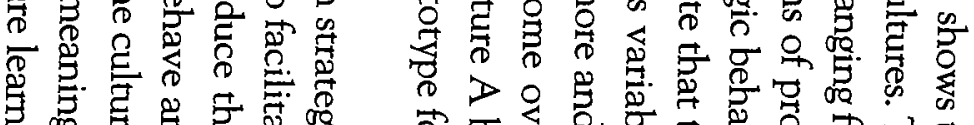

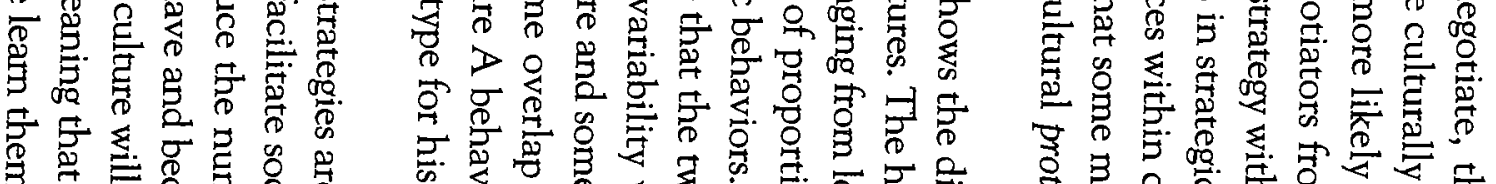

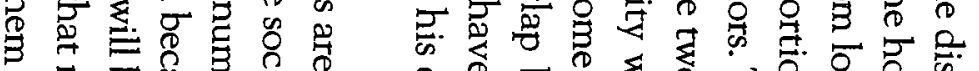

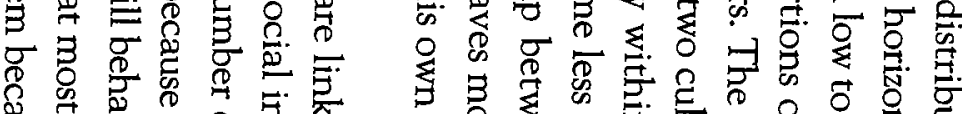
帝

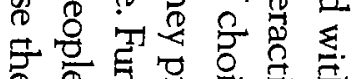

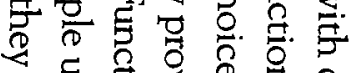

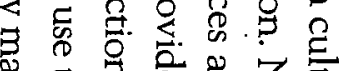

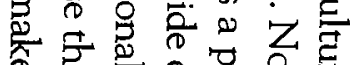
क

○ 8 贾

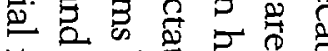

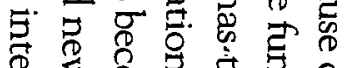

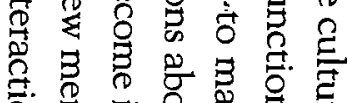

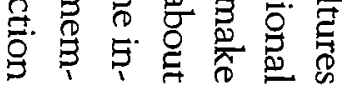

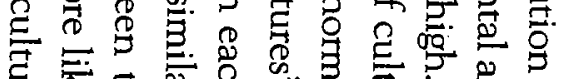

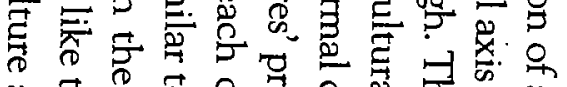

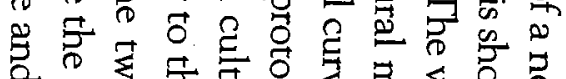
¿. \.

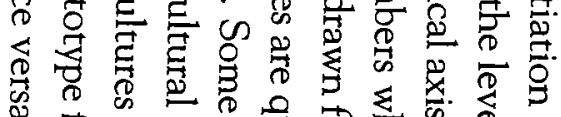
के $\overrightarrow{0}$ की क्ञ

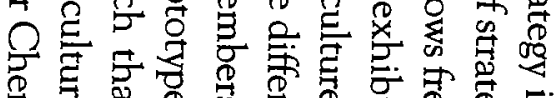

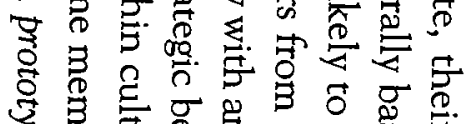

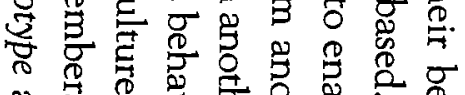

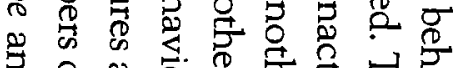

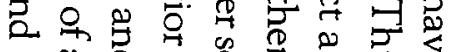

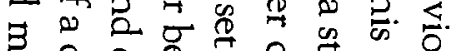

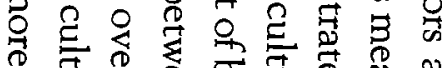

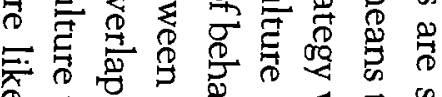

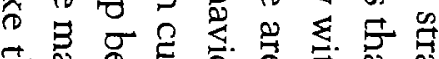

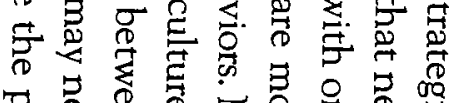

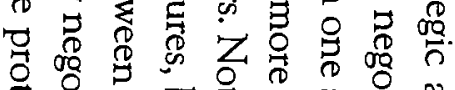

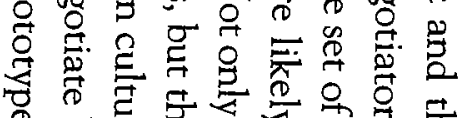

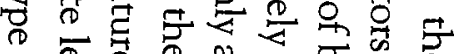

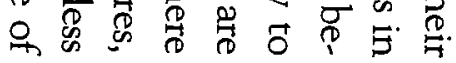

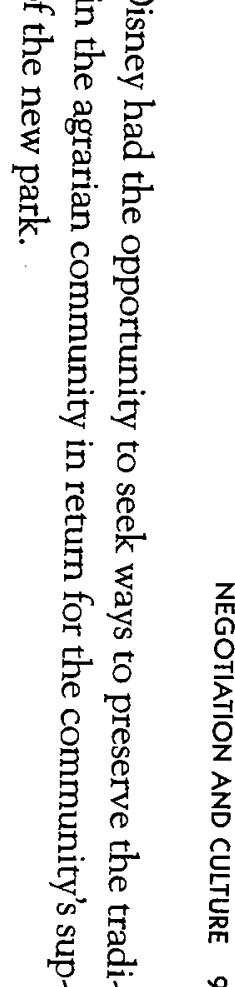




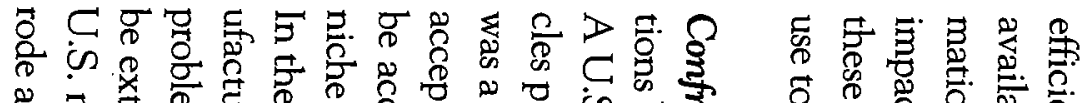

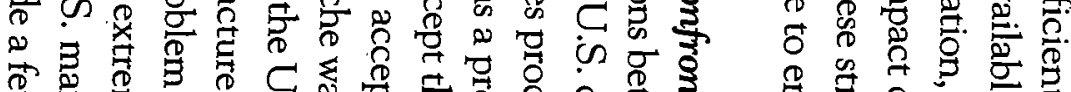

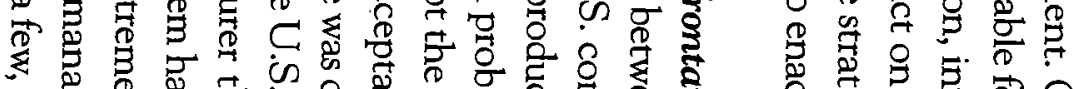

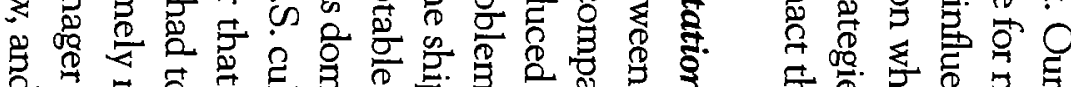

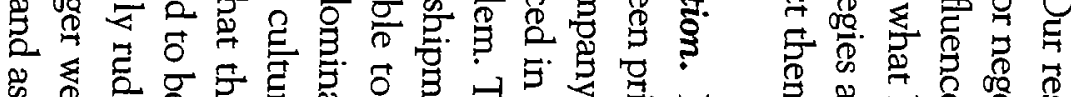

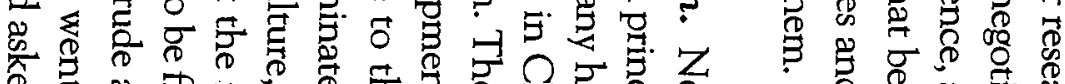

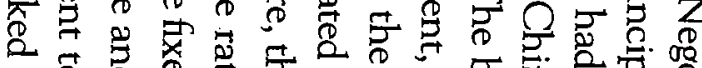

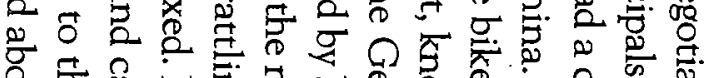

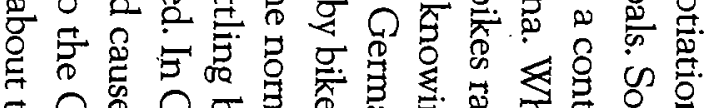

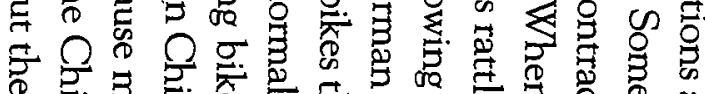

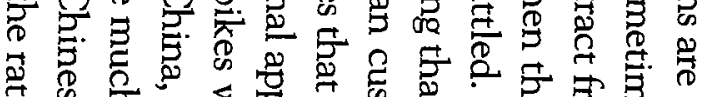

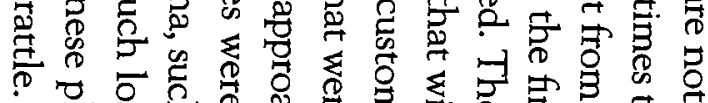

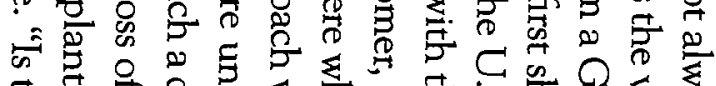

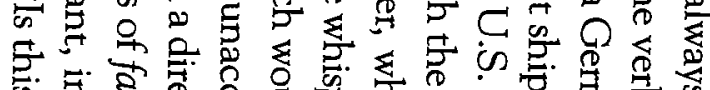

क ₹

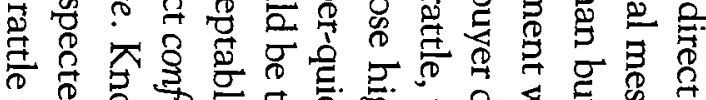

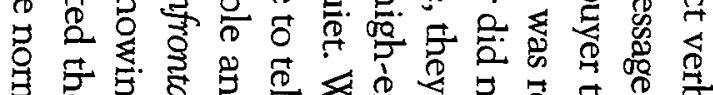

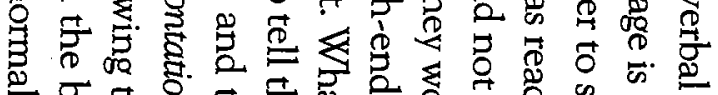

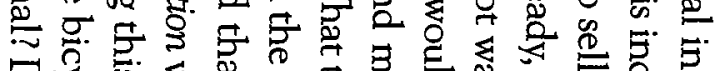

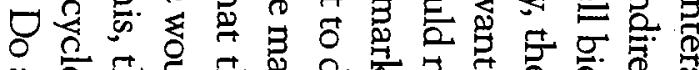

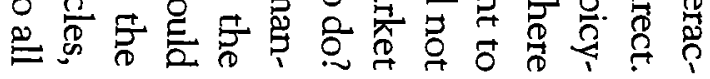
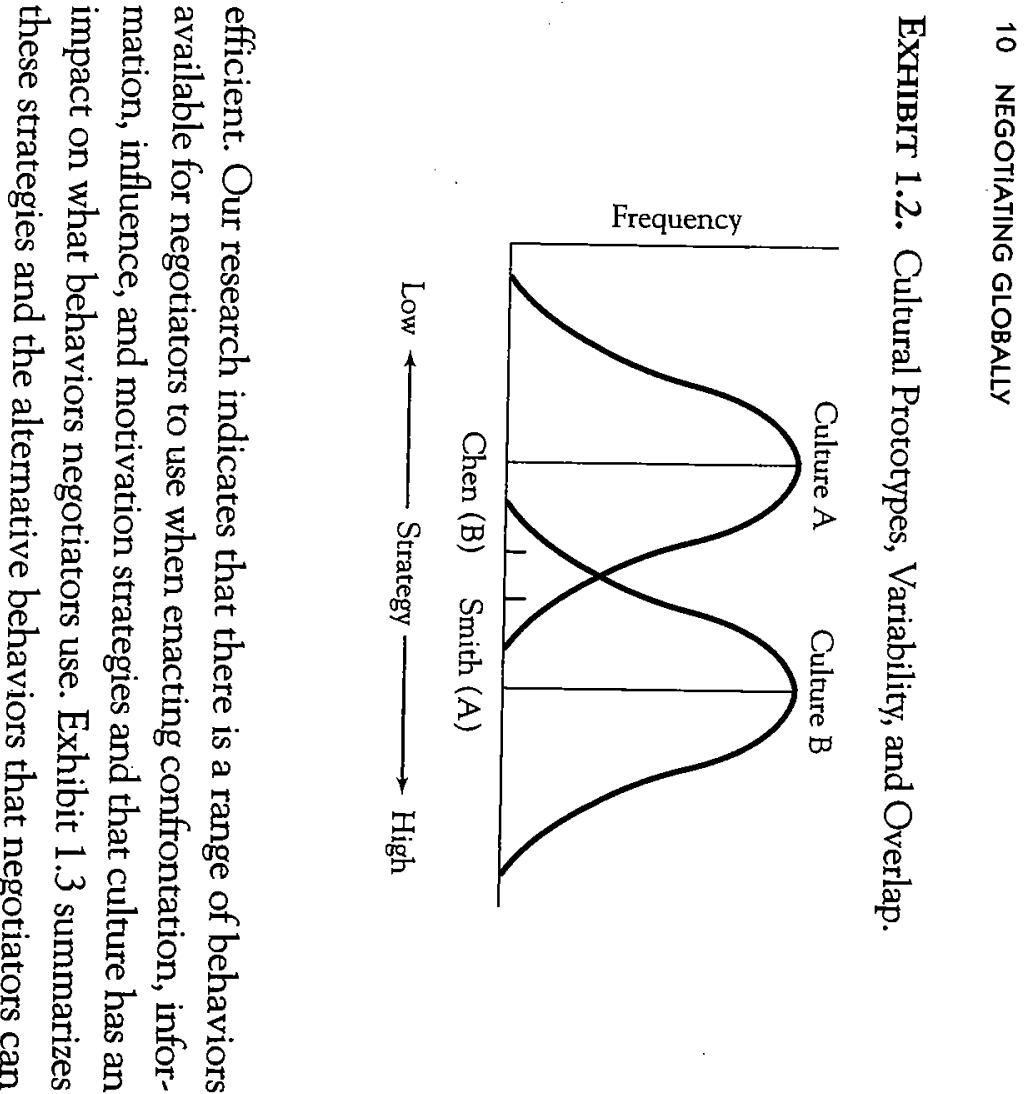

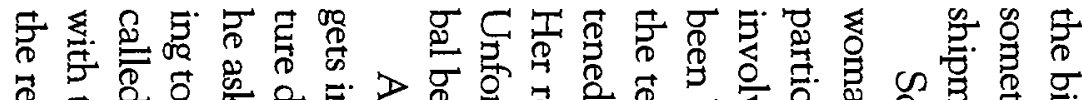

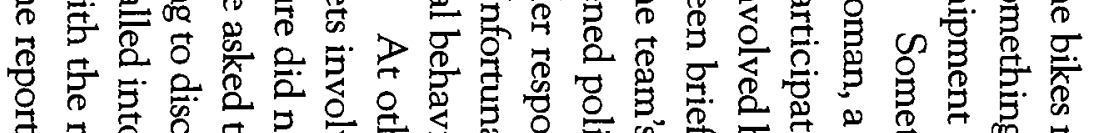

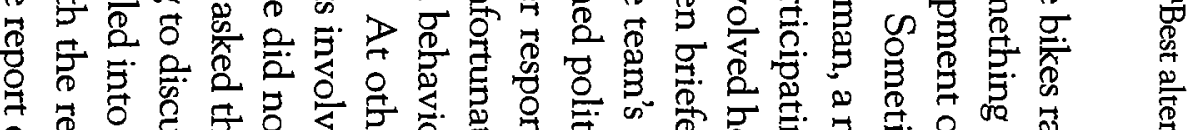

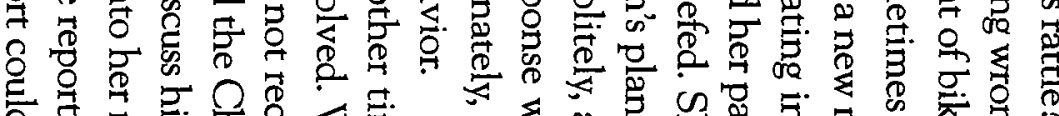

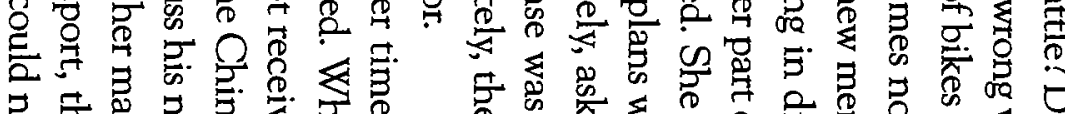

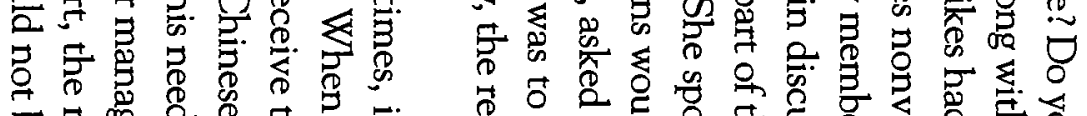

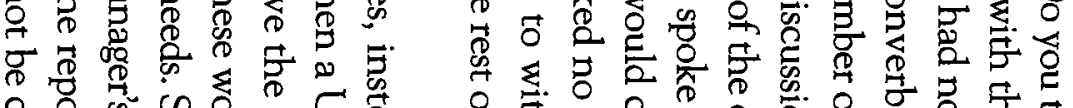

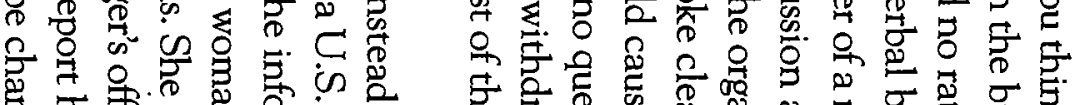

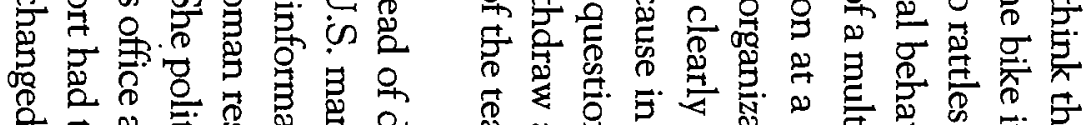

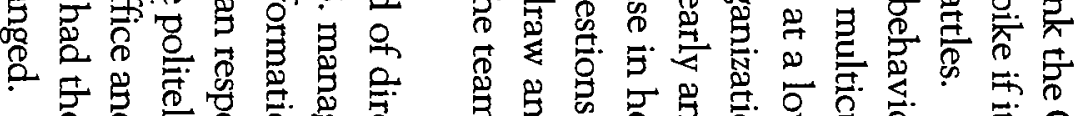

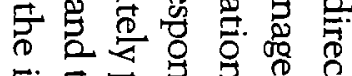

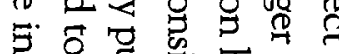

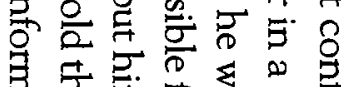

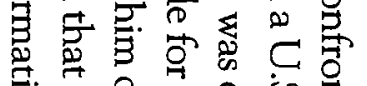

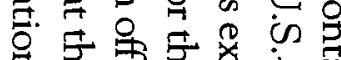

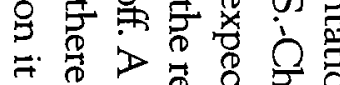

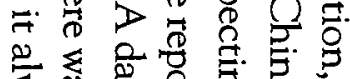

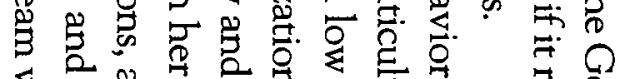

₹

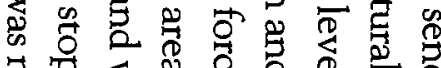

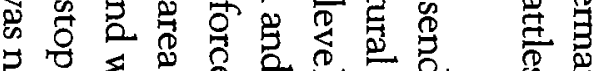

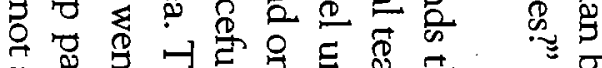

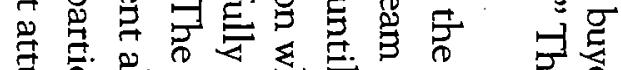

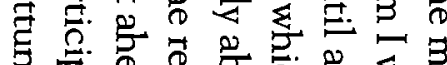

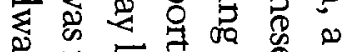

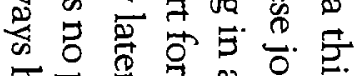

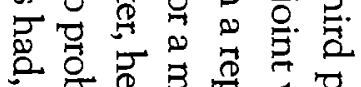

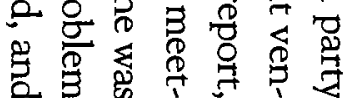

है

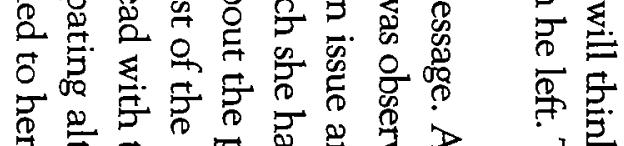

吾定

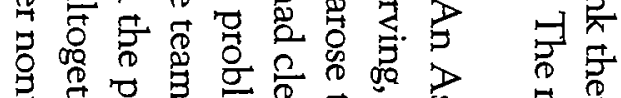

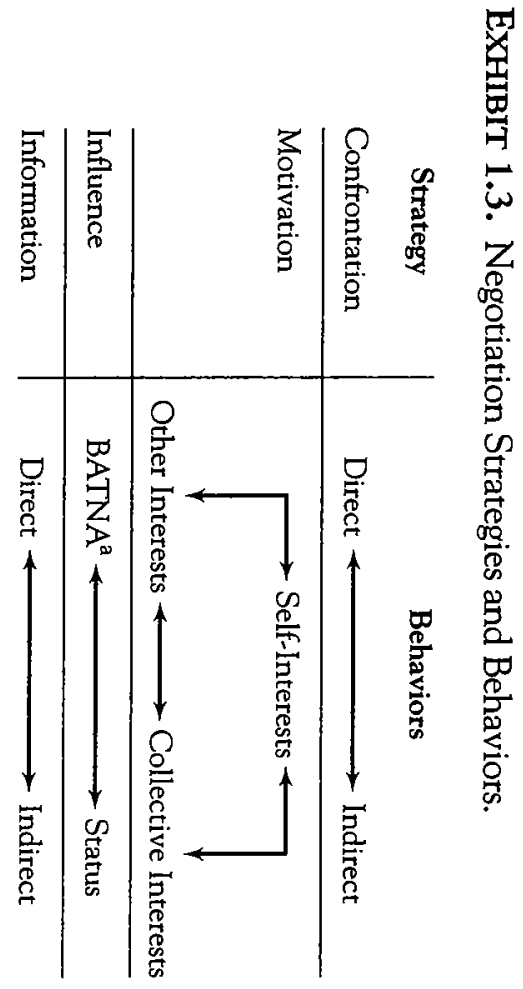

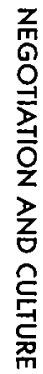




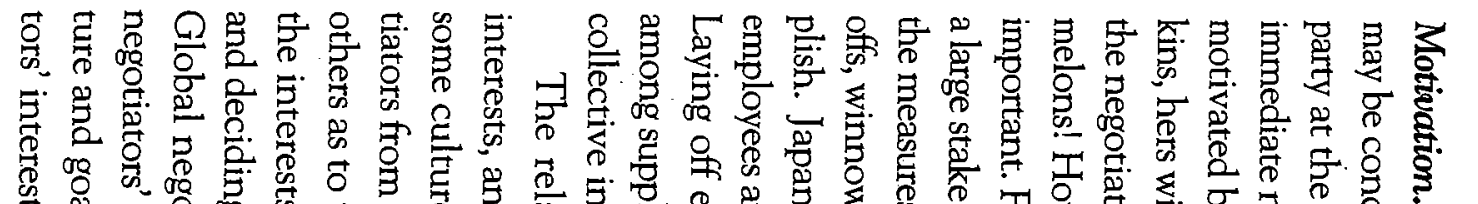

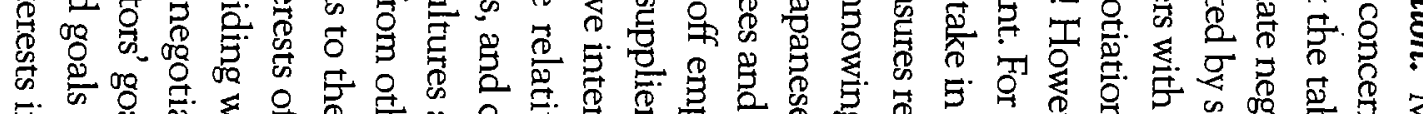

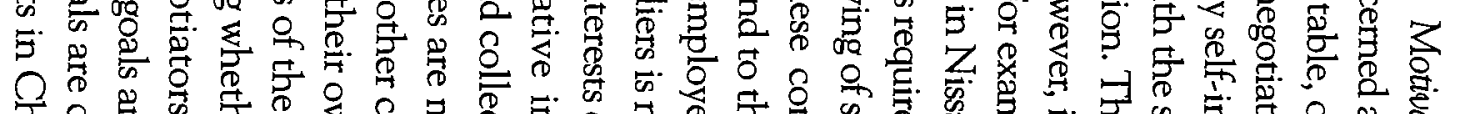

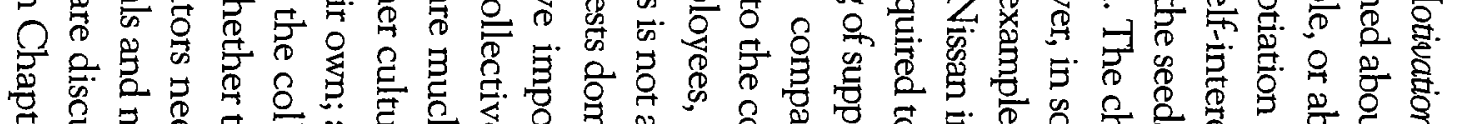

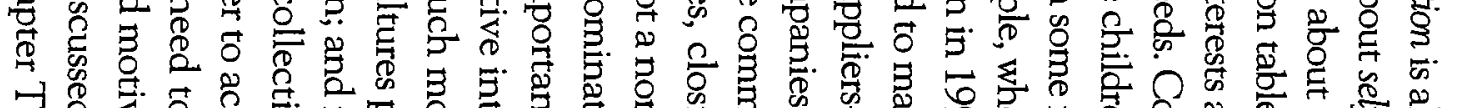

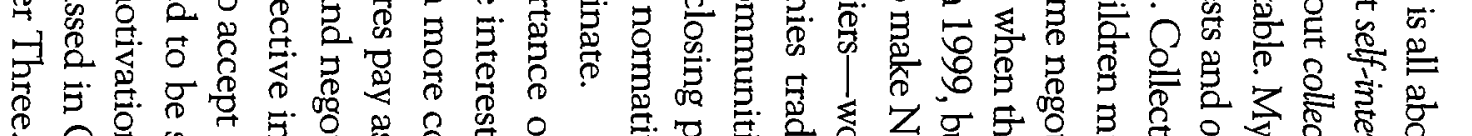

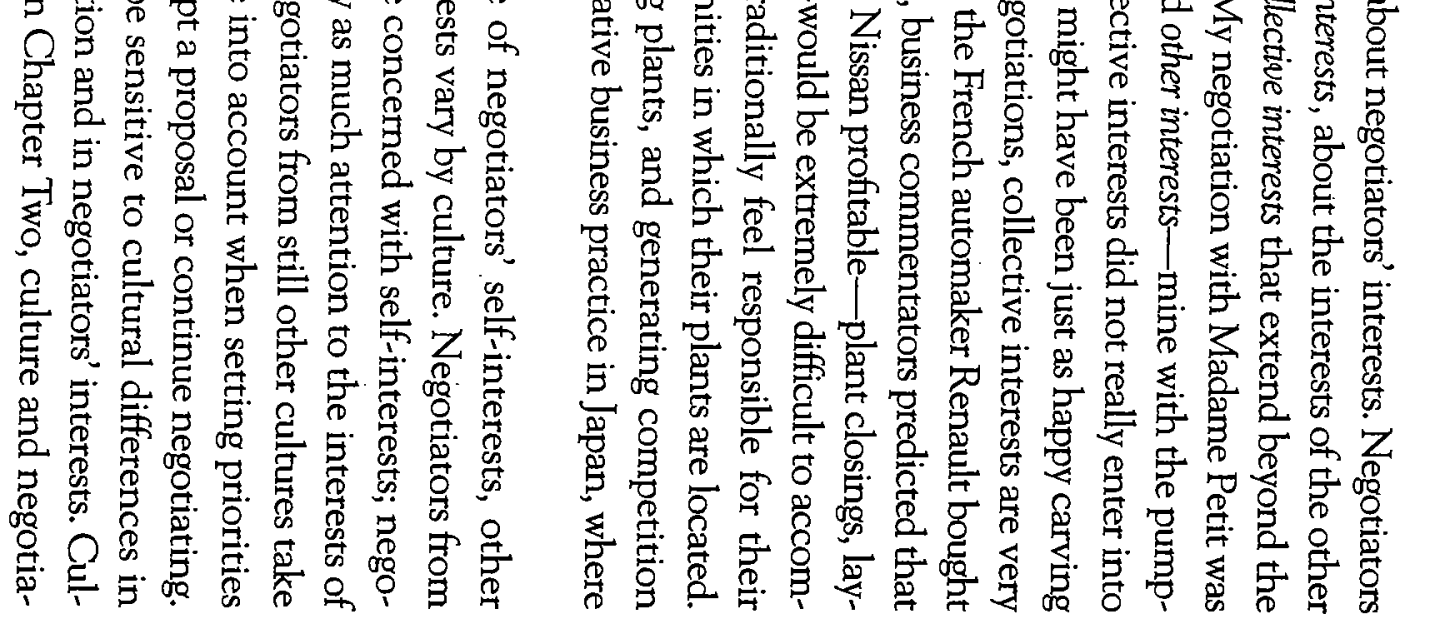

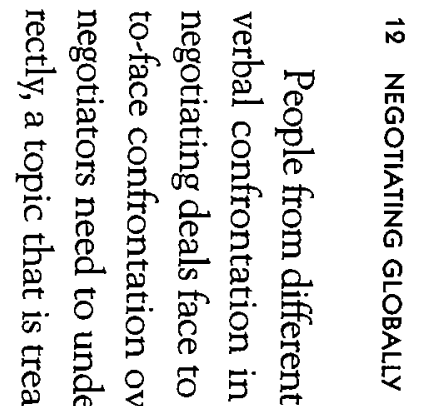

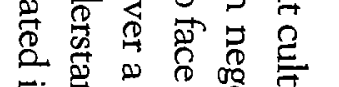
so

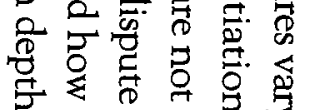

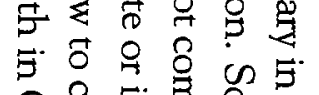

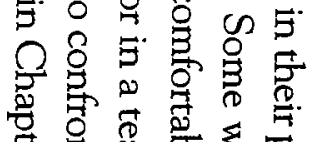

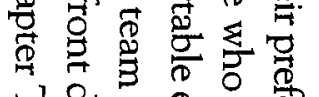

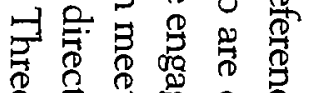

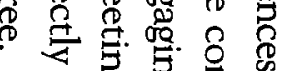

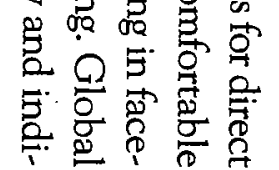



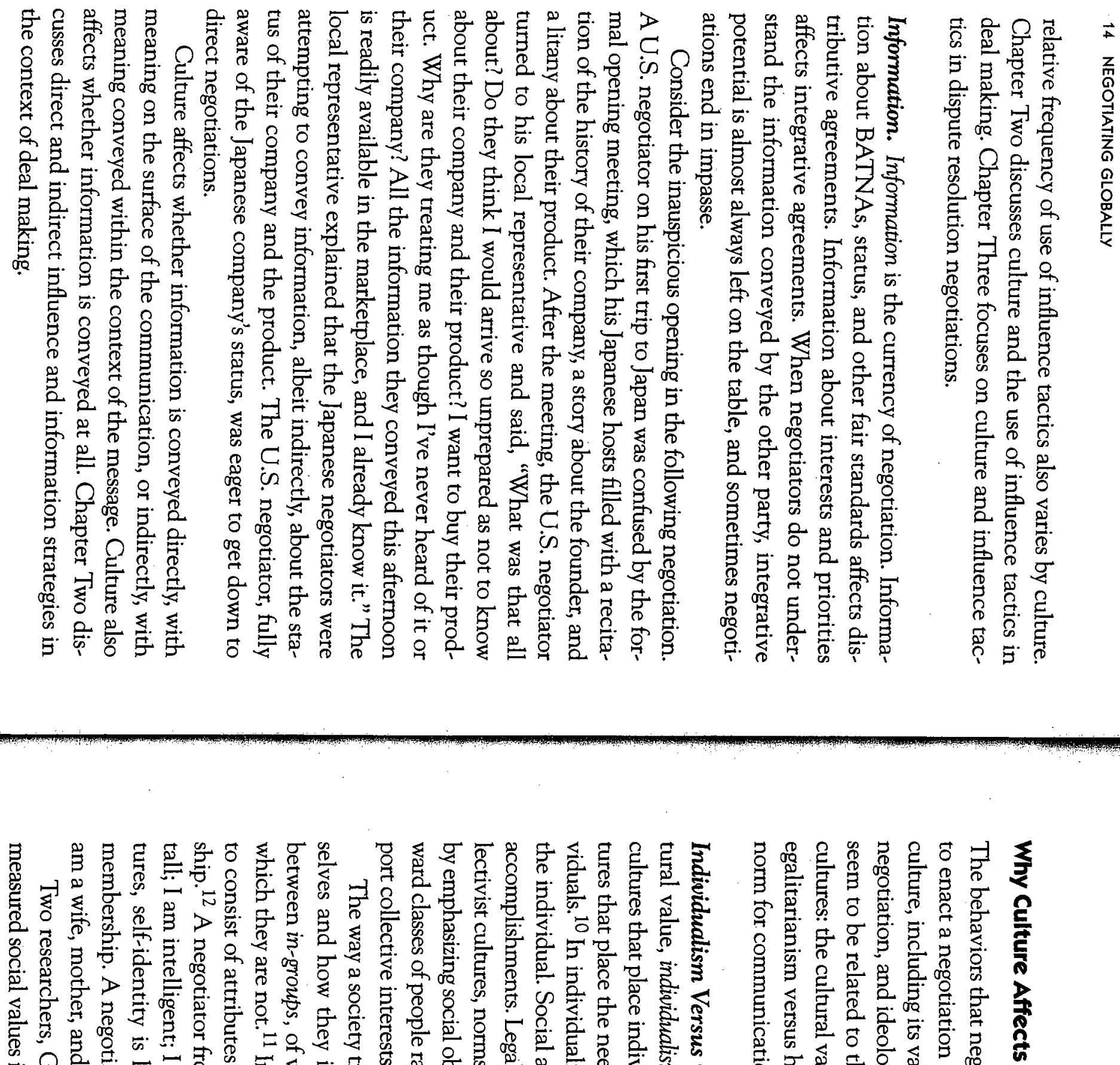

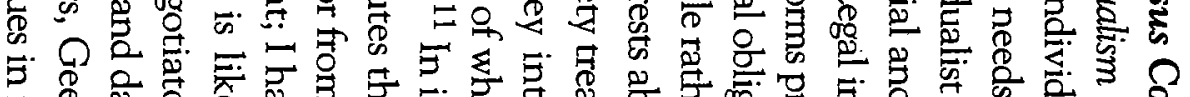

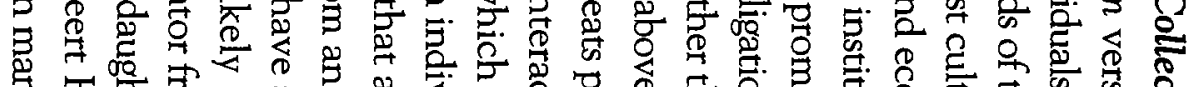

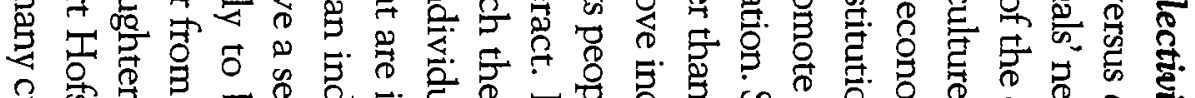

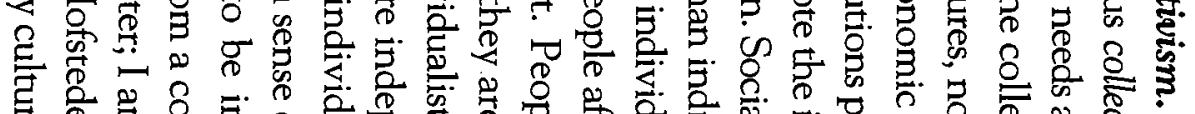

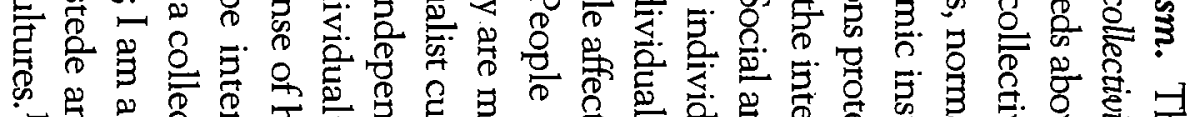

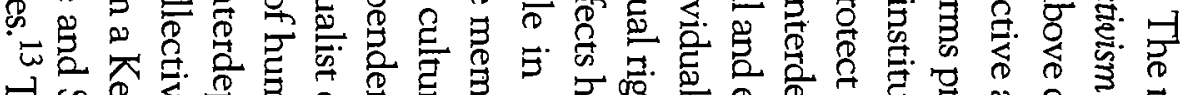

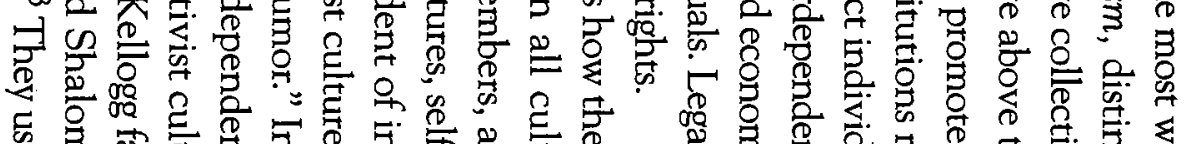
等

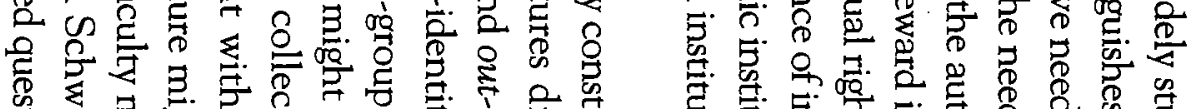

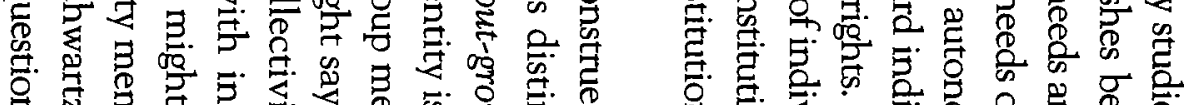

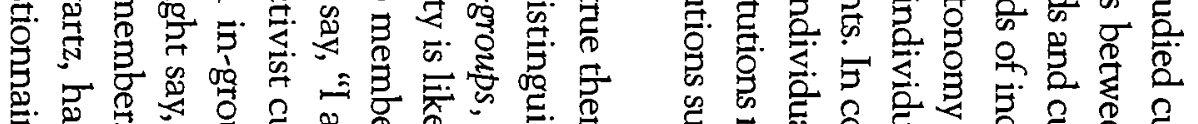

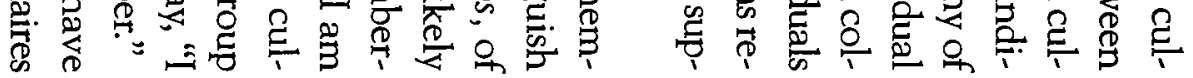

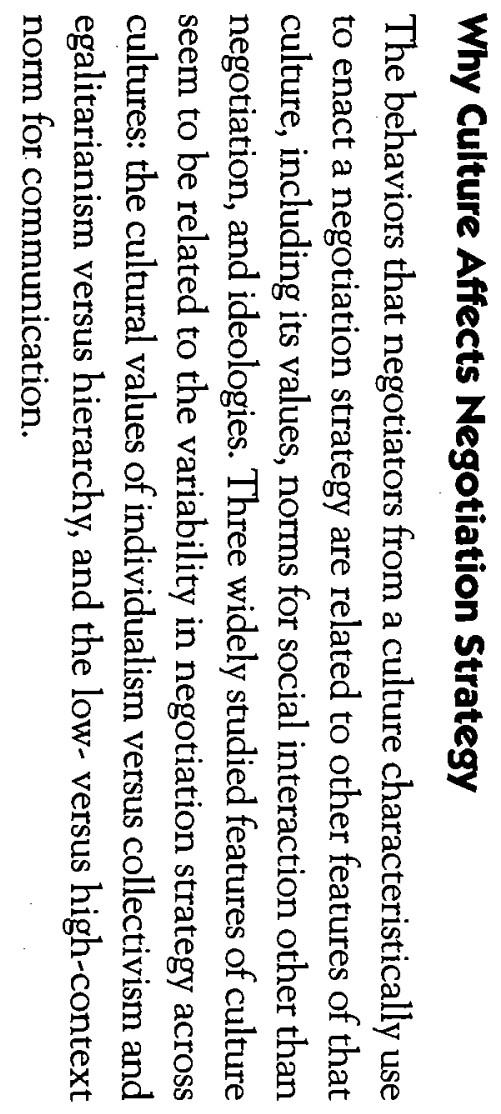



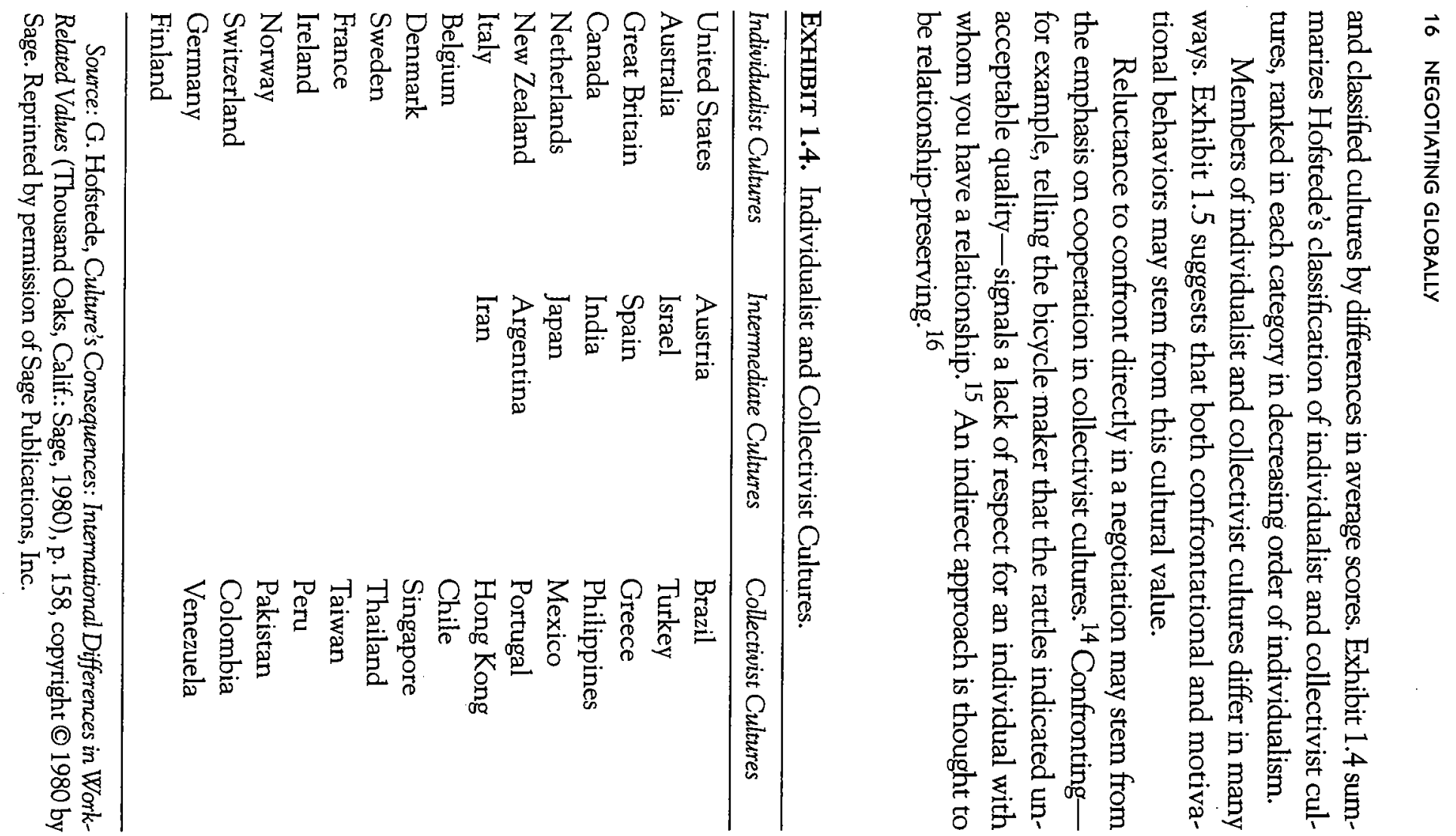

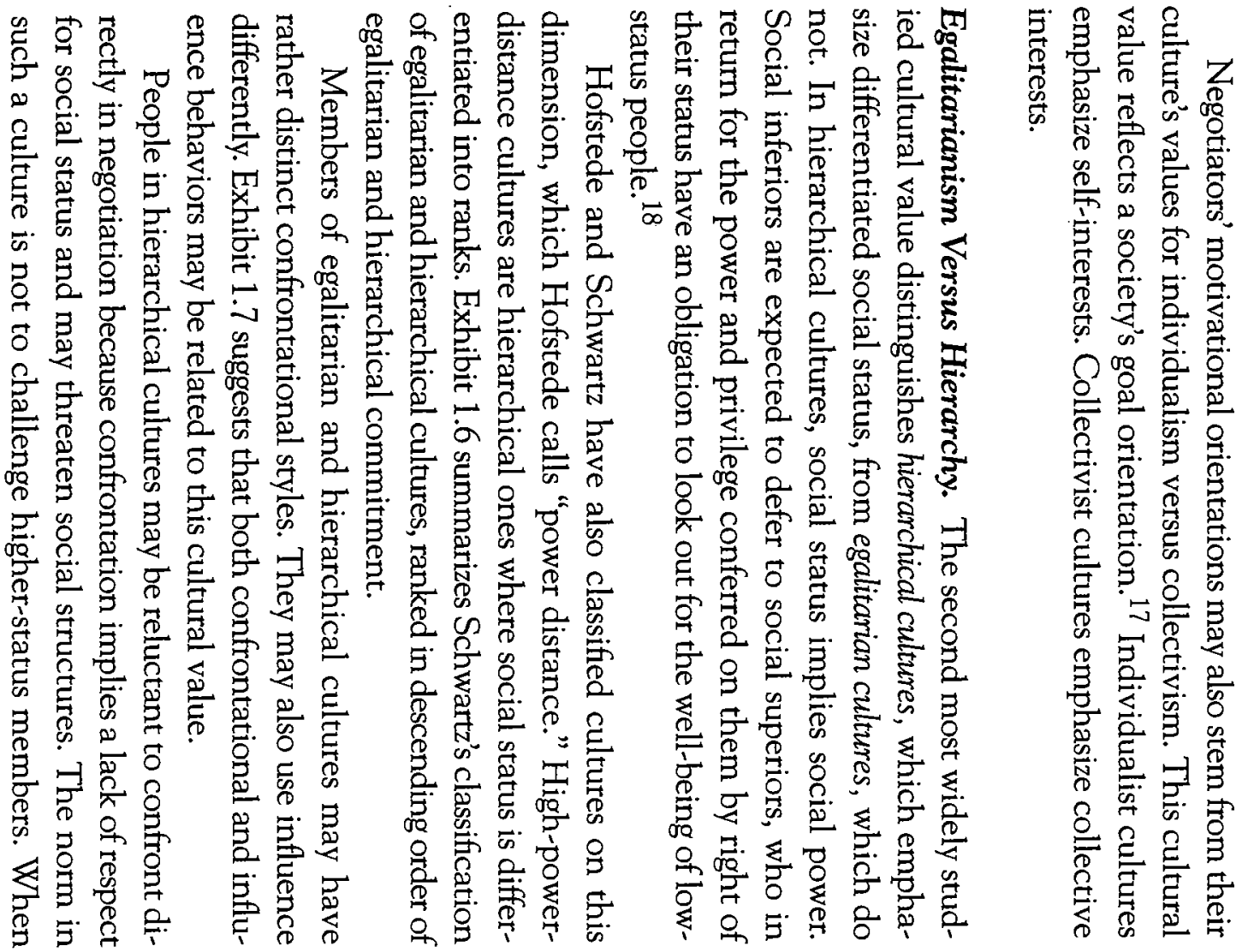

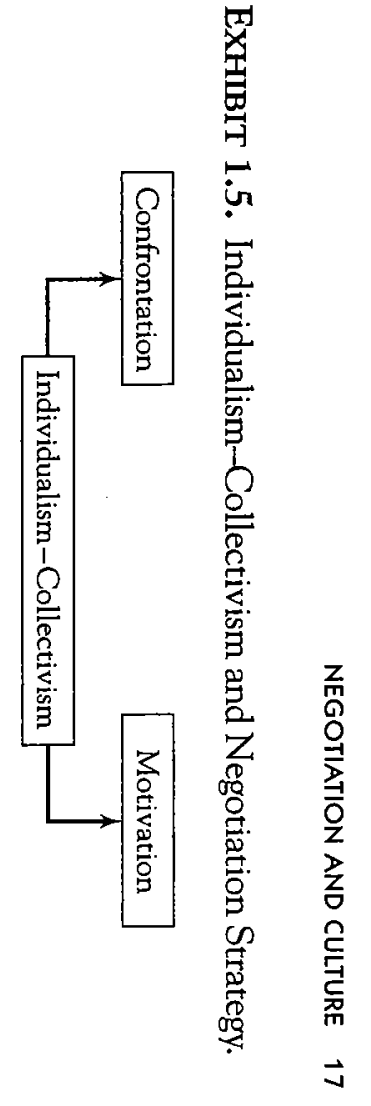




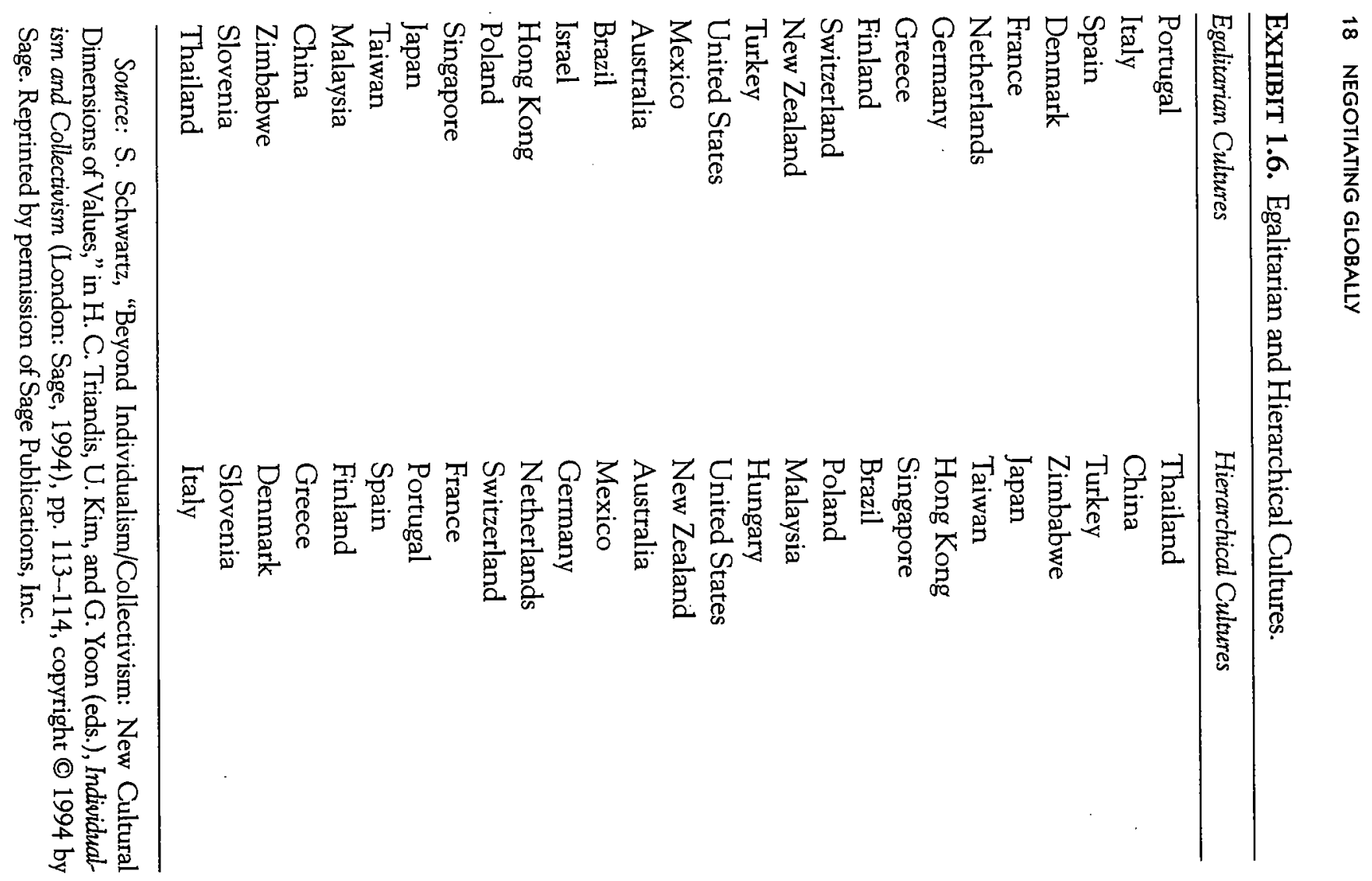

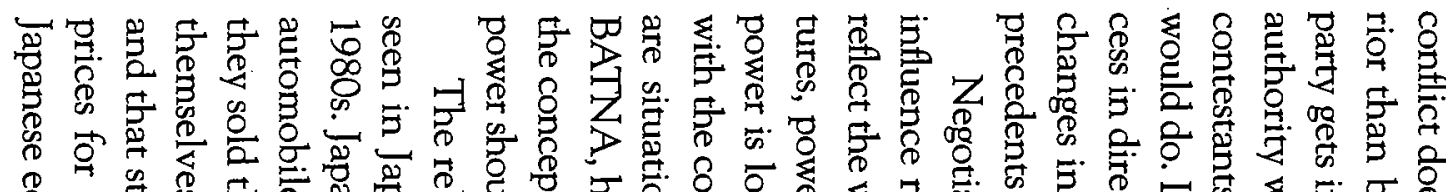

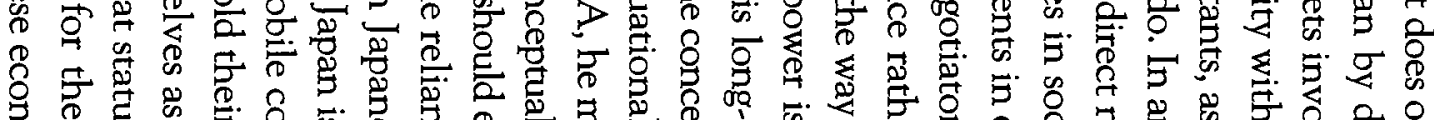

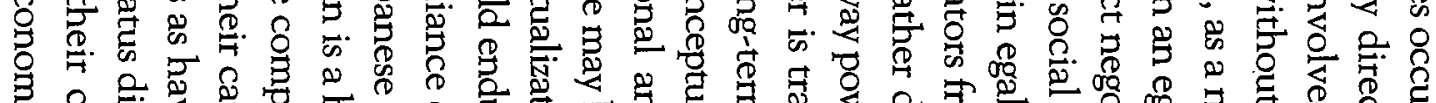

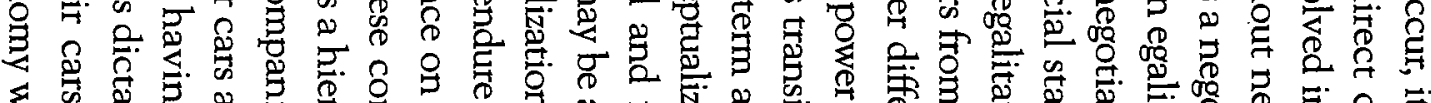

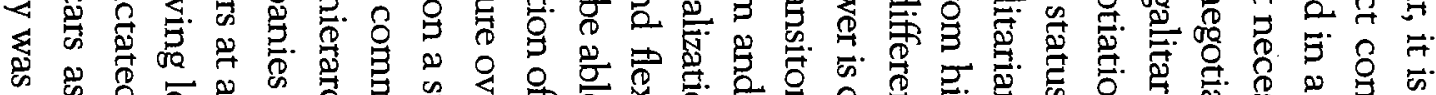

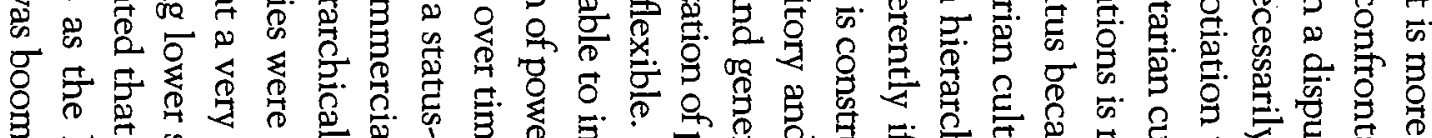

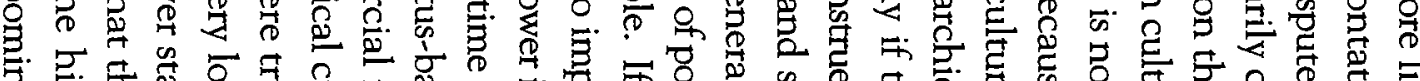

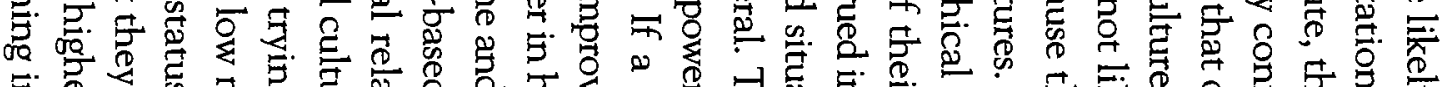

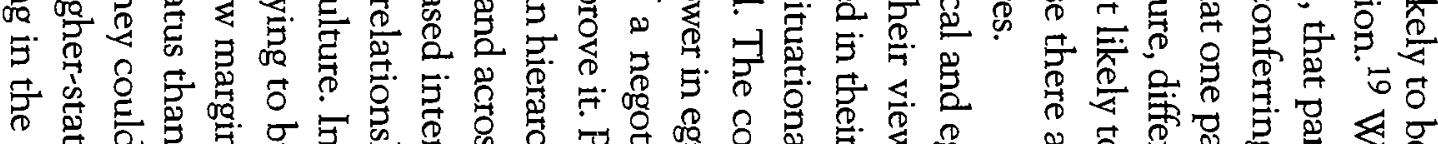

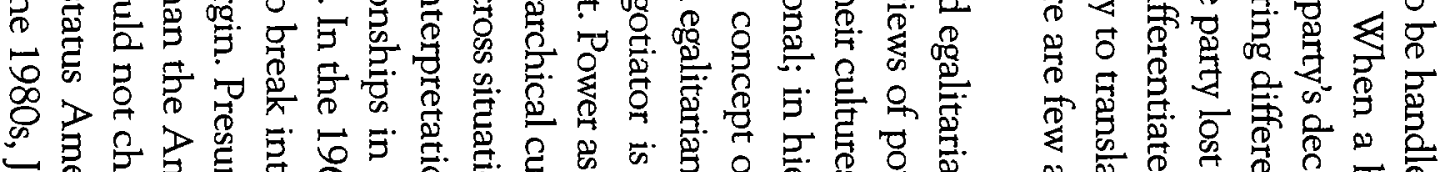

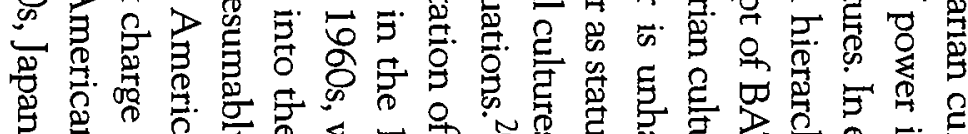

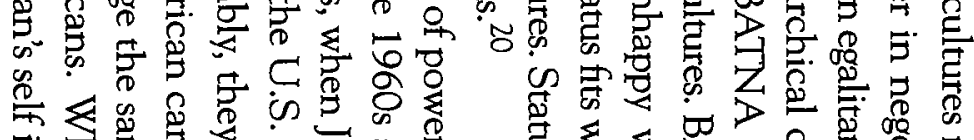
$\begin{array}{llll} & \\ 0\end{array}$

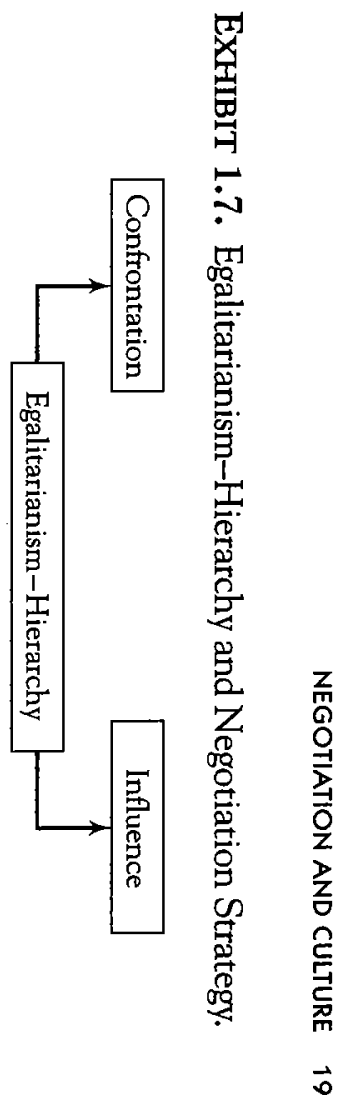




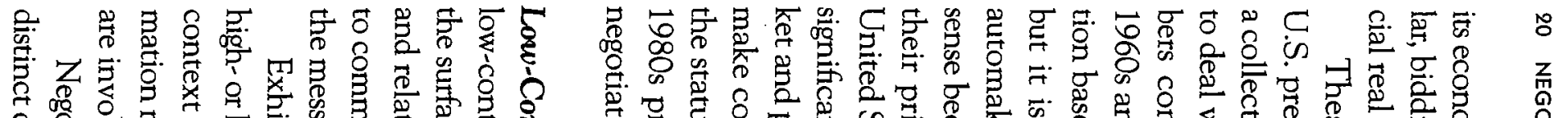

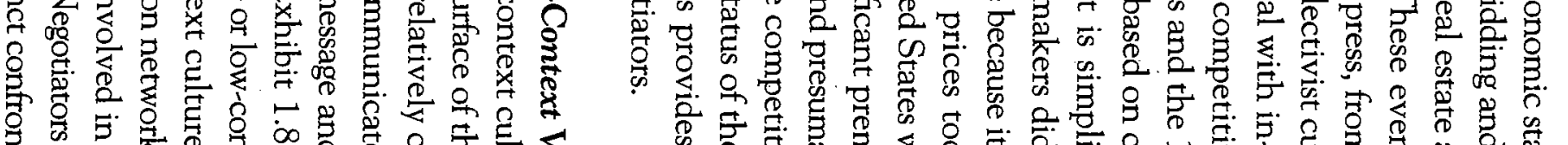

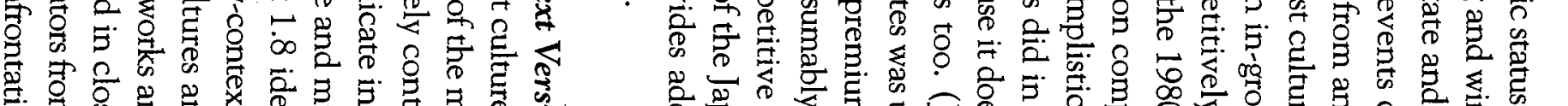

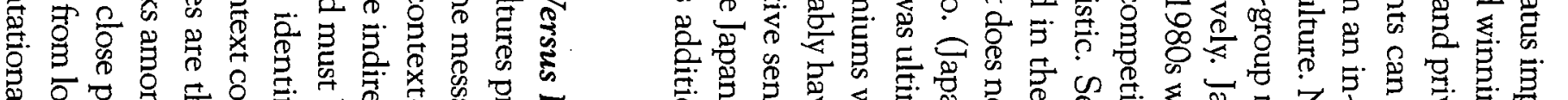

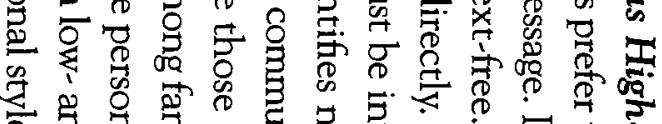

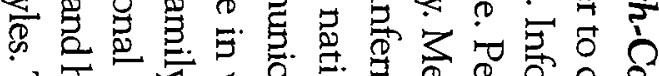

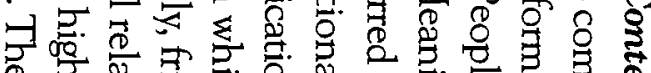

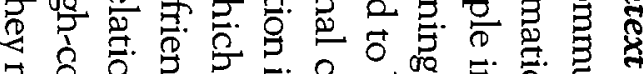

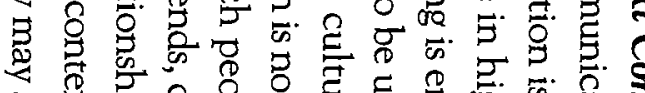

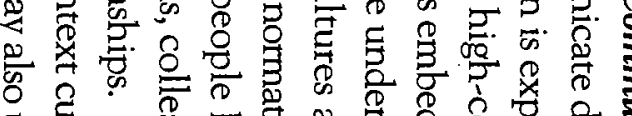

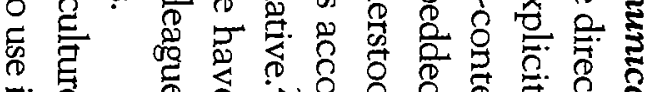

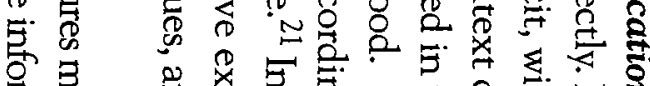

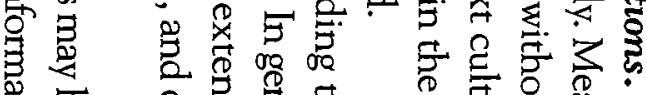
.

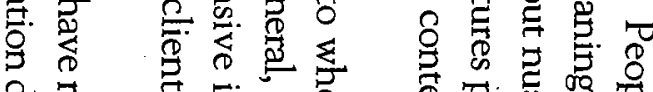
然尊

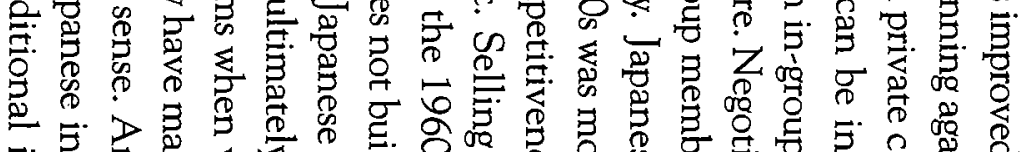
F.

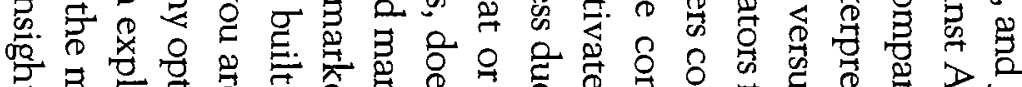

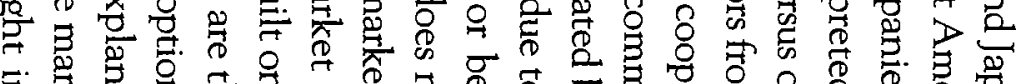

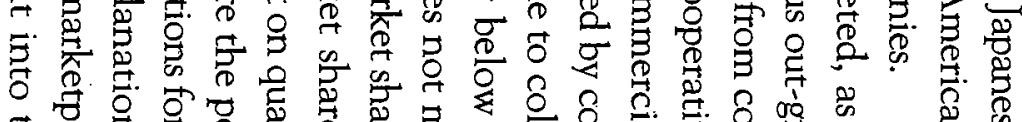

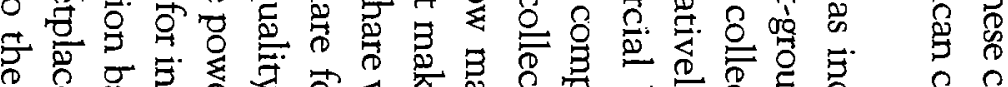

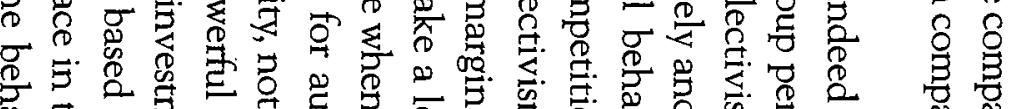

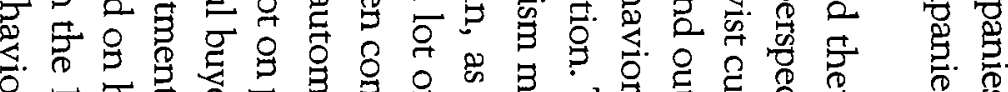
다을

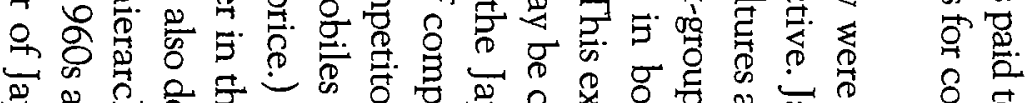

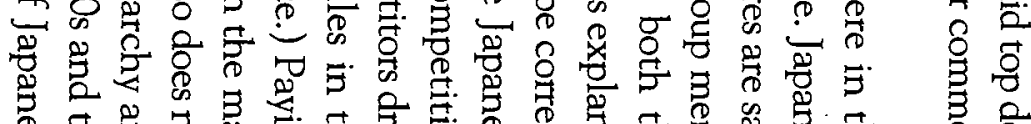

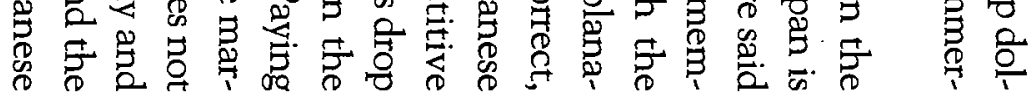

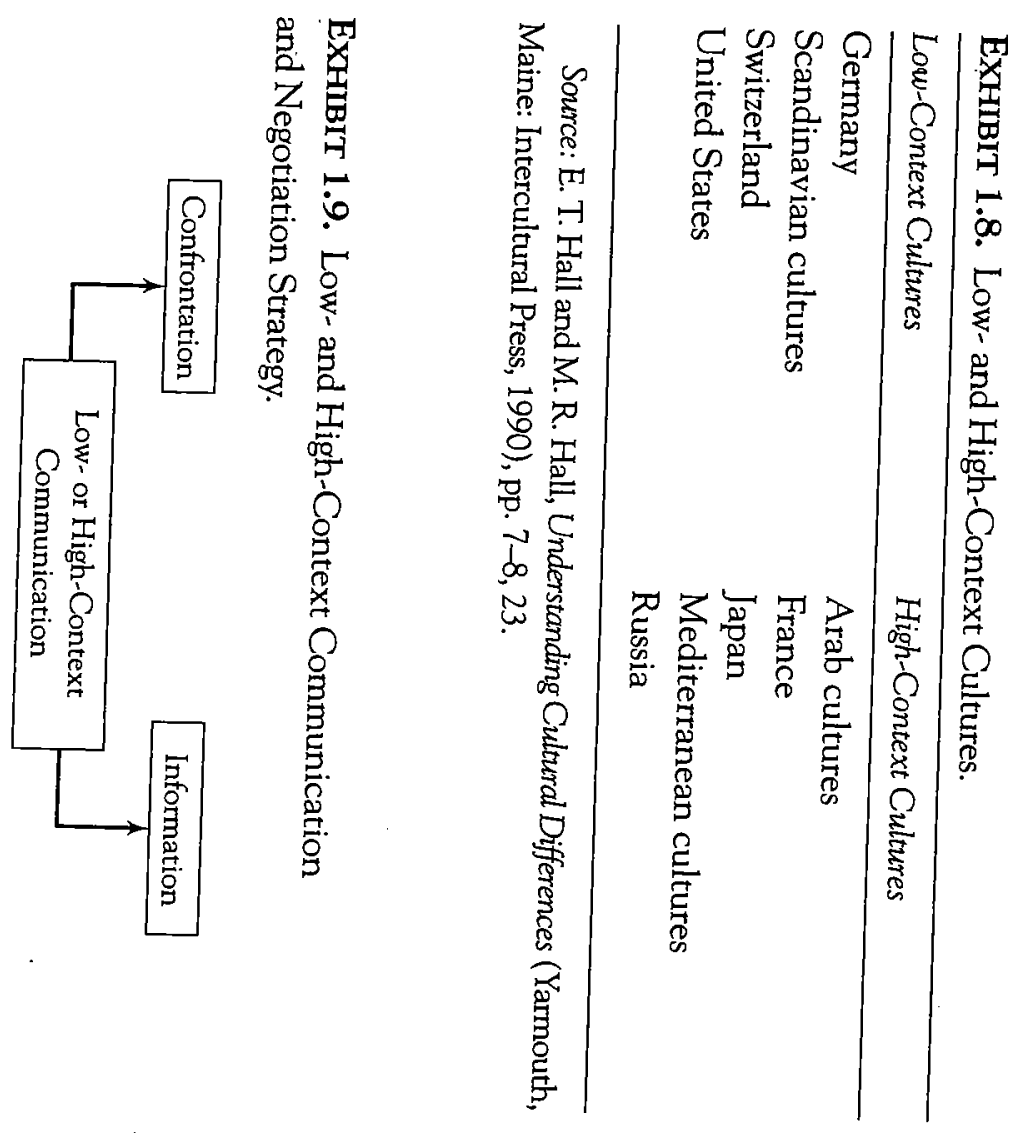

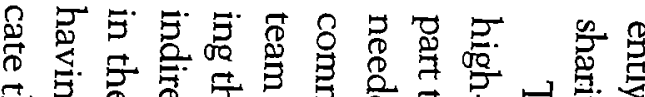

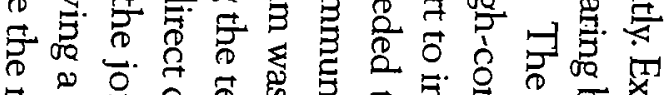

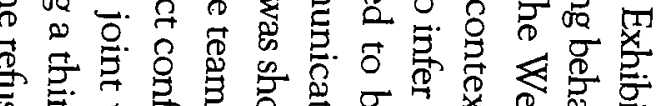

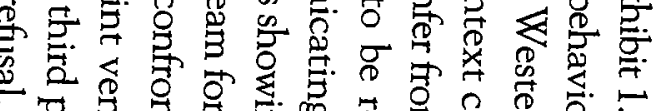

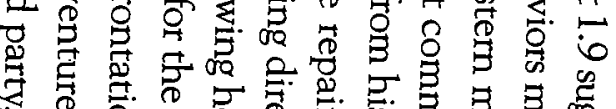

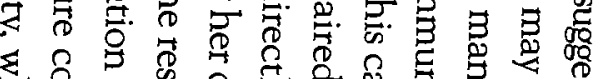

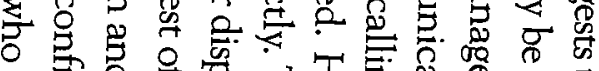

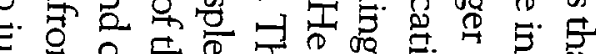

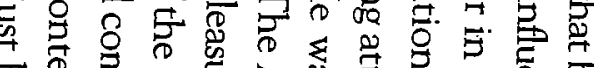

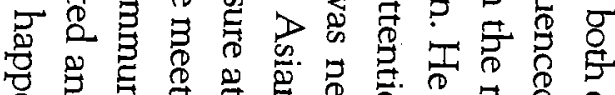

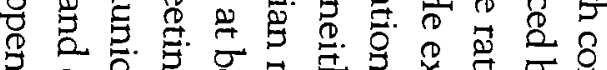

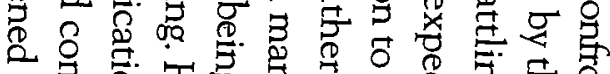

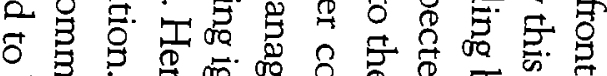

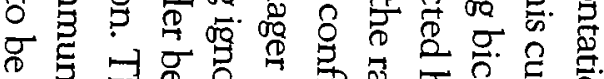

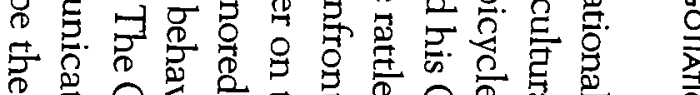

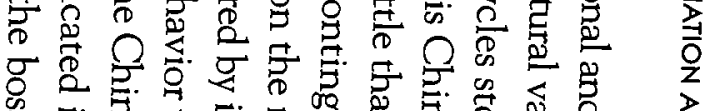

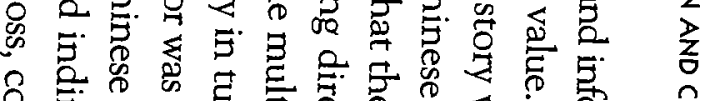

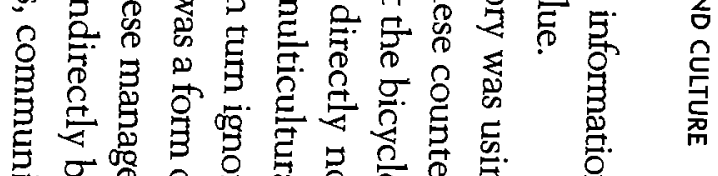

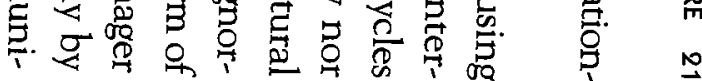




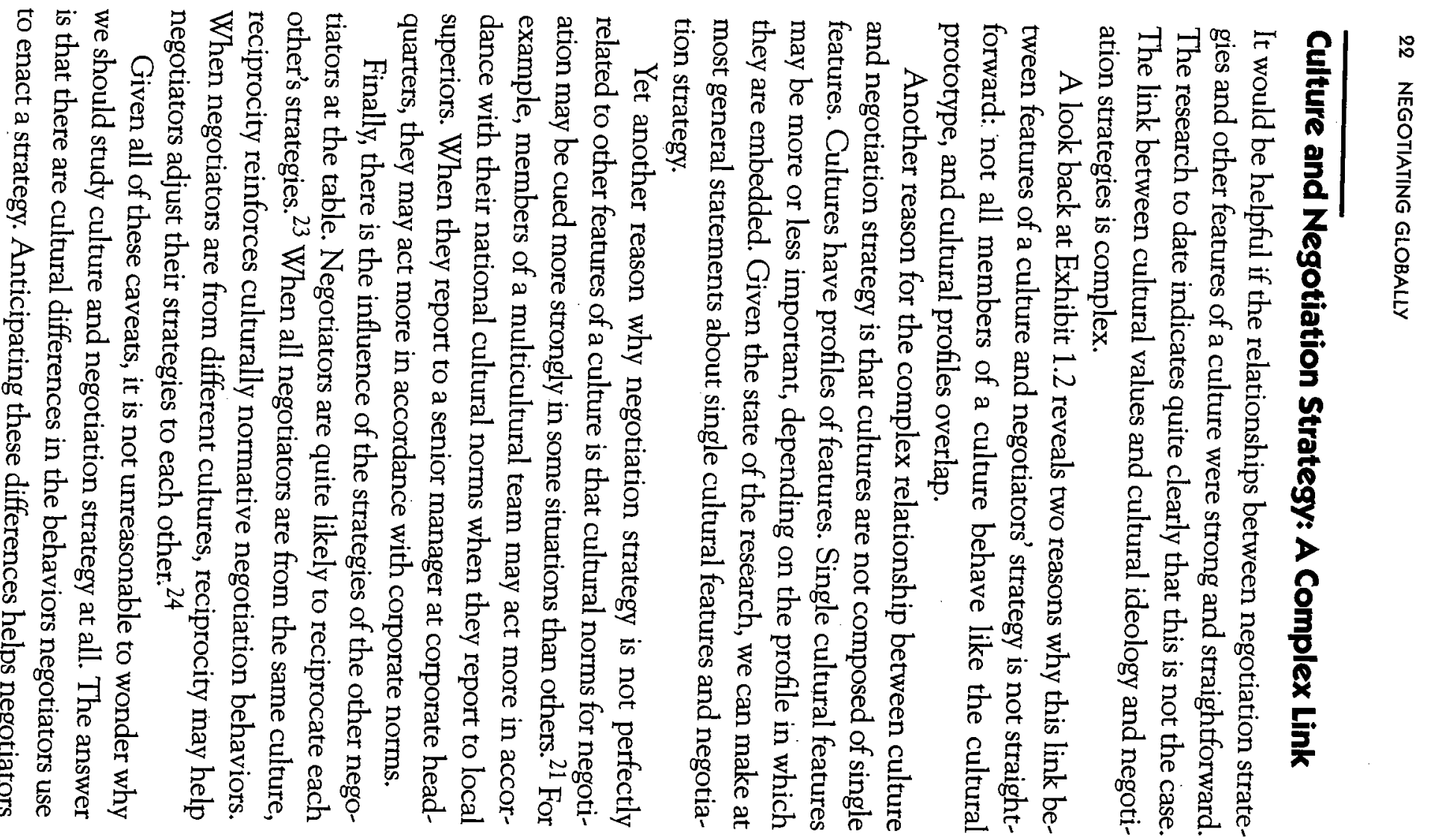

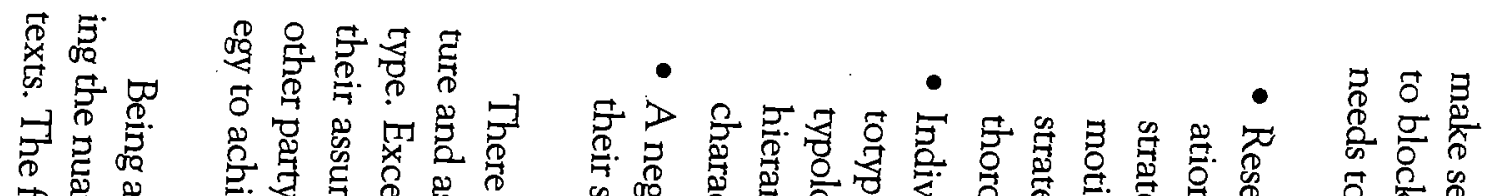

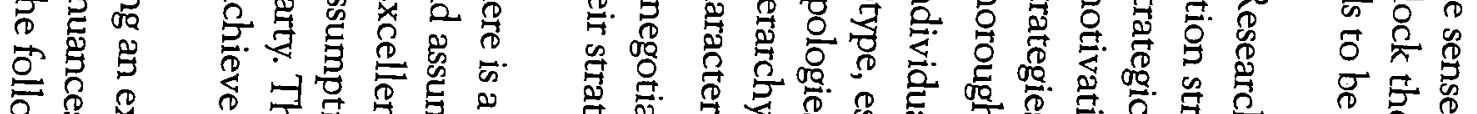

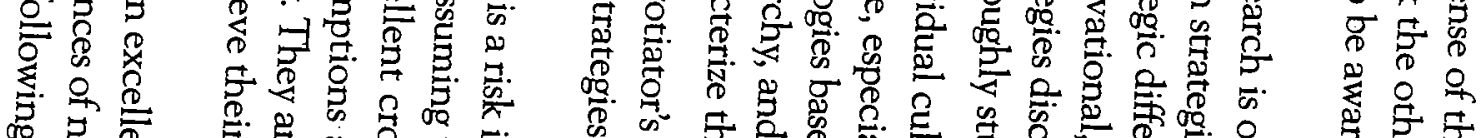

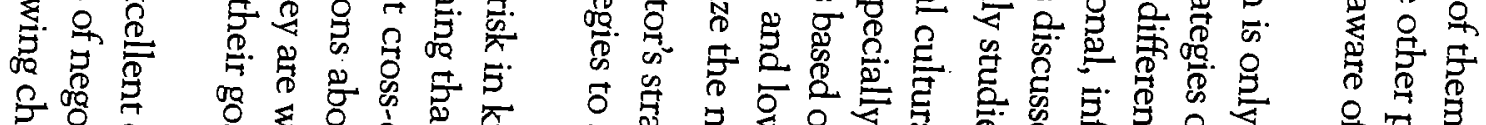

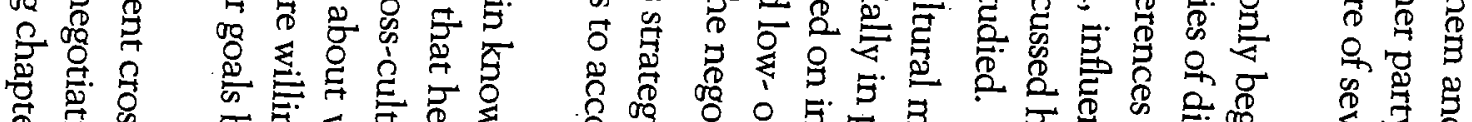

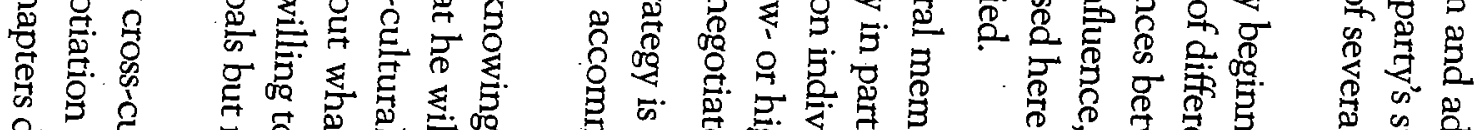

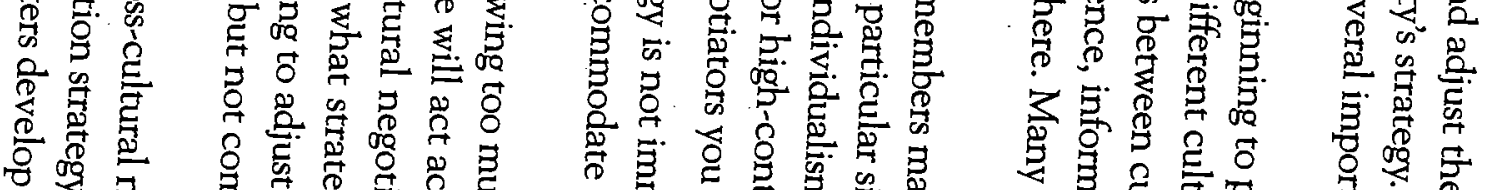

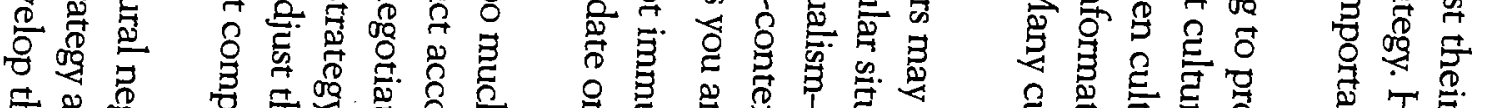

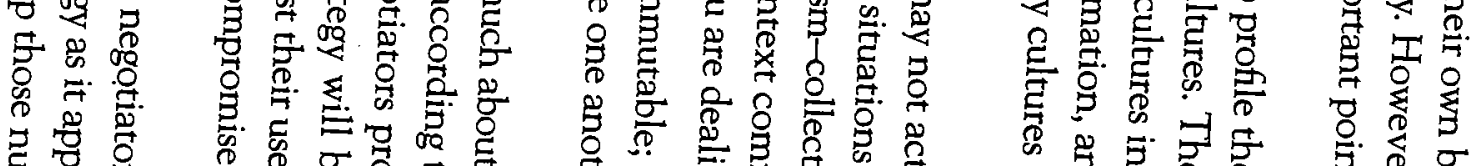

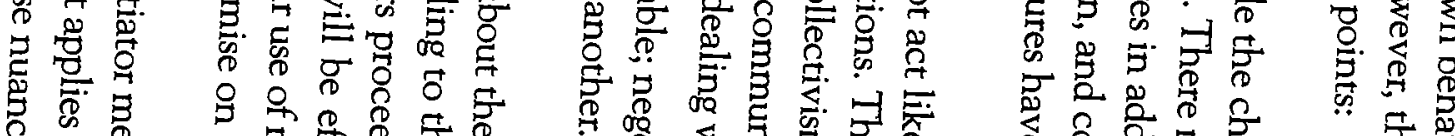

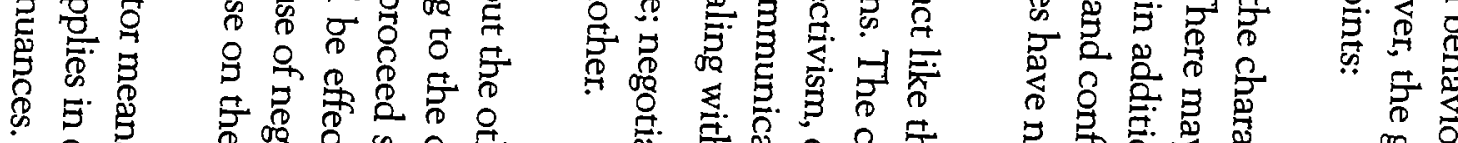

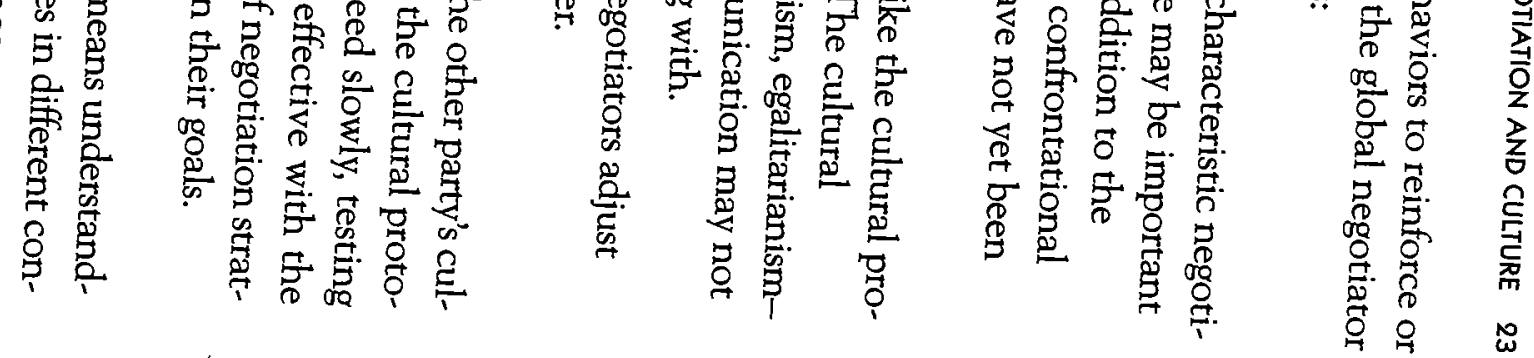

